\title{
CROSS-SECTIONAL REVIEW OF MORBIDITY AMONG YOUNG SOLDIERS
}

\author{
BY
}

\author{
S. ROSENBAUM
}

Army Medical Statistics Branch, The War Office

\section{INTRODUCTION}

The term cross-sectional implies that, for a period such as a month or a year, one is considering all cases that occur during that period; when the population is changing, the cases in different periods are from different (though it may be similar) risk groups. Contrasted with this is the term longitudinal, which implies the follow-up of individuals, that is to say continuous histories. A longitudinal survey retains a clinical flavour, since the results directly portray the progress of individuals, but a cross-sectional survey is a purely statistical concept, examining some impersonal subject such as the Army, which is certainly an entity, but whose composition in terms of soldiers has a turnover of a third every year. Of course there is an overlap in the results thrown up by both methods of approach, especially when the qualities of the population remain constant from year to year. This is, in fact, exploited in the cohort type of analysis, where a group studied in one year is linked with an older group studied in a later year, thus simulating a longitudinal study.

The morbidity experience of the Army is most easily measured in terms of annual or monthly rates of sickness, that is number of cases related to numbers at risk (liable to be reckoned as cases). The latter definition, including as it does a vastly varying population, deserves closer examination that it often receives. After all, it may be said, the victims of a train crash can only come from people who ride on trains; why suppose that anyone else is at risk? The answer is first that such clear designations of a population sub-group are rarely obtainable in practice; secondly that when the population structure remains fairly constant, the experience of one sector of it will be reflected faithfully even if mildly in the experience of the whole; and thirdly that rates measured in this way reveal a stability of behaviour with respect to random causes that gives them great value in the practical and predictive sense. The interpretation of a changing rate is far more frequently to be found in the changing circumstances of the population at risk than in the casualties themselves; thus the proportion of train crash victims among the population at large increased as more people used the railways, not because the human frame became more susceptible to flying debris.

\section{Population at Risk}

We must now seek to specify the population at risk which is the subject of this review, and whose morbidity experience can be taken to represent the state of health of National Servicemen. National Service goes back to just before the war, to the summer of 1939, when the conscripts were commonly spoken of as militiamen. At that time the age at call-up was 20 , and the period of service, with the outbreak of war, stretched to 6 years and more. At the end of the war men were being called up for much briefer periods. By 1948 a number of Acts of Parliament had been passed which were consolidated into the National Service Act of July 30, 1948, providing for a boy's call-up (with exceptions) on reaching the age of 18, for a whole-time service of one year. This was amended from December 16 of the same year to a period of 18 months, and subsequently from September 18 , 1950 , to 2 years. (These Acts are jointly known as the National Service Acts 1948 to 1950.)

Meanwhile the strength of the Army had run down by 1949 to under half a million men, and remained at about this level for another 8 years or so. During this period also the National Service and Regular elements were more or less balanced, and although since 1952 with the introduction of a 3-year Regular engagement a considerable proportion of National Servicemen signed on for a third year, they were in a 
sense doing an extended form of National Service, since many would not have become soldiers without it. By 1957 these two classes actually accounted for about three-quarters of the Army strength. The inclusion of the remainder does not raise the average age of the whole Army much above that for the National Servicemen alone, and it is reasonable to suppose that the average morbidity experience for the whole Army reflects the morbidity of National Servicemen alone. This is borne out by actual comparisons; for example, a count of in-patient records for all diseases in the United Kingdom in 1954 produced a rate for National Servicemen of 18 per cent. of strength as against a rate for Regulars of 17 per cent.

From several points of view, this study is best based on the 7-year period from 1950 to 1956. It was a period when the run-down of the large war-time Army had been completed, and a fairly stable composition had been reached in regard to age and the service structure in the Army. From 1956, a rather later call-up age was gradually being introduced with the object of contracting the Army, and National Service was made more selective with regard to medical standards.

This period is also convenient from the point of view of control charts, discussed below.

\section{MORBIDITY RATES}

IMPORTANCE OF GeOgRAPHICAL Differences.Morbidity rates form an index to the health of the Army, which can be regarded in the manner of a control chart as a guide to preventive measures and a yardstick of their success. Examples of charts are given in Fig. 1 (opposite) allowing for observations on a monthly basis against the background of knowledge of the preceding 7 years. No account is taken of age, since we are dealing with a fairly narrow age-group (and of one sex) which is scarcely changing in composition during this time. It is also of convenience from the point of view of making probability statements: avoiding the inadequate basis of binomial probabilities for fixing limits, we can use the observations themselves in the following way. The two maximum and two minimum rates for the 7 years are plotted as a pair of outer and inner limits, and form boundaries such that one in eight of subsequent observations may be expected to be record high ones, and another one in eight record low ones; half the subsequent observations may be expected to lie within the inner limits. These localized extrema, it must be repeated, have engaged our attention because in a longer period the homogeneity of the population vanishes (quite apart from the inevitable changes in the collection of data; before the war, for example, many cases would have been treated as "sick in barracks").

The rates have been calculated quite simply from returns of admissions to hospital supplied monthly by all Army medical units (and civilian hospitals treating Army patients), while the numbers at risk were obtained from a monthly census. There is a long history of morbidity measurement in the Army, similar to that of mortality in civilian terms; both were founded by the same generation of early Victorian pioneers in medical statistics, and it was immediately seen that the Army gave the opportunity for the numbers of cases of diseases and of persons at risk to be known with some certainty, so that a precise measure of sickness could te made. This is an index to disease just as mortality is, though with a very different emphasis, and a lesso sharply-defined boundary, but nevertheless in Army. terms a fairly consistent one, the criterion being a stay of over 48 hours in a medical unit.

We look first to total admission rates to show the level of morbidity in the Army. In a relatively brief period such as we have chosen, the composition of the total admissions in terms of particular diseases is reasonably stable, whereas over longer periods different groups come to dominate the picture as do respiratory conditions in Great Britain to-day. Table I shows the total admission rates for the chosen 7 years in the United Kingdom, and in each of the three main commands overseas where the overwhelming majority of troops have served, the British Army of the Rhine (B.A.O.R), the Middle East Land Forces (MELF), and the Far East Land Forces (FARELF).

TABLE I

TOTAL ADMISSIONS OF BRITISH ARMY IN MAIN COMMANDS, 1950-1956 RATES PER 1,000 STRENGTH

\begin{tabular}{|c|c|c|c|c|c|c|c|c|c|c|c|c|}
\hline \multicolumn{4}{|c|}{ Command } & 1950 & 1951 & 1952 & 1953 & 1954 & 1955 & 1956 & Average & Range \\
\hline $\begin{array}{l}\text { UK } \\
\text { BAOR } \\
\text { MELF } \\
\text { FARELF }\end{array}$ & $\begin{array}{l}\ldots \\
\ddot{*} \\
\cdots\end{array}$ & $\begin{array}{l}\ddot{ } \\
\cdots \\
\cdots\end{array}$ & $\begin{array}{l}\cdots \\
\cdots \\
\cdots\end{array}$ & $\begin{array}{l}310 \\
371 \\
461 \\
674\end{array}$ & $\begin{array}{l}314 \\
360 \\
443 \\
623\end{array}$ & $\begin{array}{l}307 \\
280 \\
399 \\
510\end{array}$ & $\begin{array}{l}338 \\
296 \\
372 \\
474\end{array}$ & $\begin{array}{l}286 \\
267 \\
284 \\
470\end{array}$ & $\begin{array}{l}265 \\
276 \\
298 \\
387\end{array}$ & $\begin{array}{l}256 \\
232 \\
327 \\
443\end{array}$ & $\begin{array}{l}297 \\
297 \\
369 \\
512\end{array}$ & $\begin{array}{r}82 \\
139 \\
177 \\
287\end{array}$ \\
\hline Range & $\ldots$ & $\ldots$ & $\ldots$ & 364 & 309 & 230 & 178 & 203 & 122 & 211 & & \\
\hline
\end{tabular}



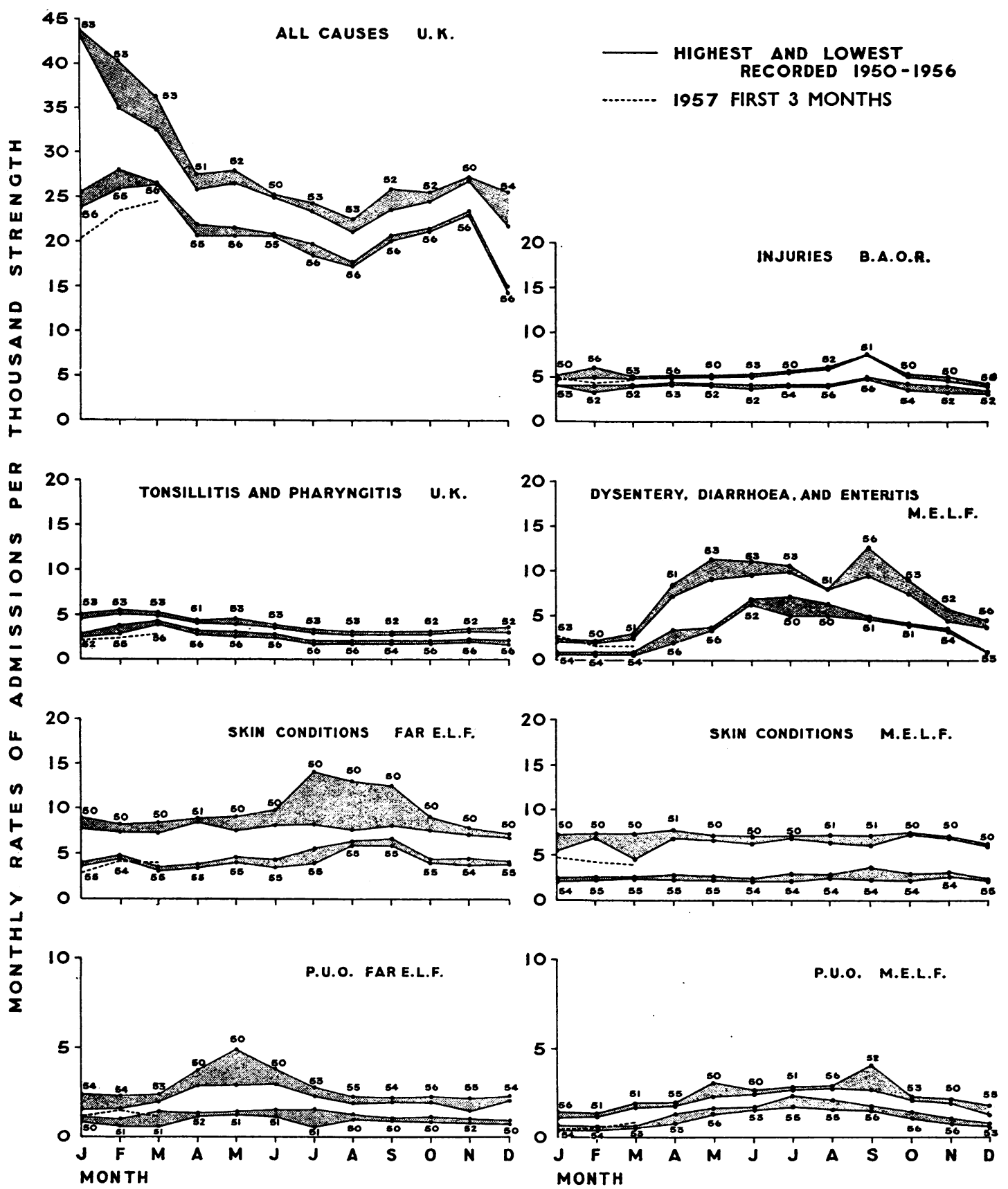

Fig. 1.-Monthly rates per 1,000 strength of admissions of British Army males to all medical units in the first 3 months of 1957 , with the two maximum and two minimum rates between 1950 and 1956.

It is to be expected that, on account of random causes alone, an average of one year in eight will lie in each of the shaded areas and in each extreme region outside them. Care should be taken in combining observations, because neighbouring months may be correlated in diseases with seasonal effects, and cannot therefore give independent evidence. 
Ranges are given between years and between commands, from which standard deviations can be estimated approximately (allowing for the fact that there are seven years and only four commands) as 110 between commands and 60 between years. From this it is evident that geographical differences were far greater than differences between years, over a short period. Indeed sickness as a whole was surprisingly stable, especially in the United Kingdom.

It must be interpolated here that civilian figures for comparison with these do not exist. There is no equivalent in the Army to staying at home in bed for a few days home nursing, so the soldier has to go to hospital when a civilian with the same complaint would not. Even those civilian hospital statistics which are published, generally cannot be related to numbers at risk in the same way as for soldiers. When it is possible to see the relative importance of diseases without knowing the absolute rates, as in the General Register Office Study (Mackay, 1951) which relates to the first half of 1949 , it is seen that less severe diseases such as respiratory diseases and skin diseases are more prominent in the Army figures while tuberculosis and peptic ulcers for example are higher for civilians (in approximately the same age group). But there is a more difficult obstacle. National Service was universal for the fittest 80 per cent. of the young male population, apart from some reserved occupations; it is therefore impossible to know what might have been the morbidity had they remained civilians, even if an organization existed for collecting the information. The universality of service does not permit the existence of a control group. It serves, incidentally, to underline the importance of these young men to the health of the nation, both in the morbidity experienced, and in their bequest to later years as civilians again; twothirds of them it should be said passed through the Army's ranks.

From the figures of Table $I$ it is possible to detect trends in the seven years, almost invariably of improvement; this is also seen in the charts where the upper limits are usually of the earlier years. But, as already pointed out, it is the geographical difference which is the governing factor: in Europe there was an annual admission rate of 30 per cent. of strength, whereas in the Far East the rate reached 50 per cent.

INJURIES.-The next step is to break down the overall rates to see which diseases cause most wastage, and which show a preference for different countries. Inevitably we must consider injuries, as a major preventable source of wastage, and one where the soldier runs his own occupational hazards, especially in time of war. Injuries formed about one-eighth of all admissions, and remained remarkably constant from year to year; here indeed the independent play of chance approaches somewhat nearer the classical model than among the infectious diseases. The average rates for the seven years, per 1,000 strength, were as follows:

$\begin{array}{lllll}\text { UK } & . & . & \ldots & 35 \cdot 7 \\ \text { BAOR } & . & . & \ldots & 56 \cdot 5 \\ \text { MELF } & . & . & . . & 40 \cdot 1 \\ \text { FARELF } & . & . & \ldots & 53.9\end{array}$

The standard deviation between commands is about $10 \cdot 5$; that between years is about $4 \cdot 5$.

The point to be made here is that the commands do not follow the same order as for all admissions. Germany had the highest rate (and it may be noted that Austria had a higher rate still). This cannot be more than partially attributed to traffic accidents, and some other cause must be operating, perhaps training. This is undoubtedly true if sport comes under that heading, for injuries at sport are far more numerous than any other single cause including traffic accidents, though they are less severe than those suffered through traffic accidents. A detailed survey of injuries and their causes has been made in the Report on the Health of the Army for 1954 (1958).

Diseases.-Apart from injuries, and using the term "diseases" to their exclusion, we can put the spotlight upon the main health problems by listing those rates which amount to about one per cent. of strength or more when averaged over the 7 years; this is done in Table II. (For more detail, see Appendix.)

\section{TABLE II}

DISEASES WITH AN AVERAGE RATE ABOUT ONE PER CENT. OF STRENGTH OR MORE ADMISSION RATES PER 1,000 AVERAGED OVER THE 7 YEARS 1950-1956

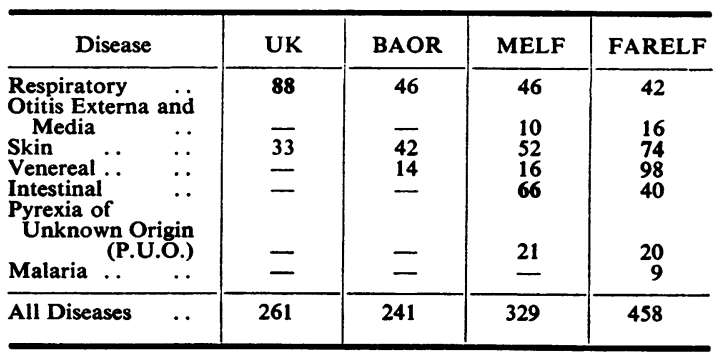

Clearly the respiratory diseases stand out in the U.K. and skin conditions in the Far East, where if it were not for venereal diseases they would be the leading cause of illness. 
Venereal Diseases.-These are in a special category in the reporting procedure, as every single case during this period was counted whether admitted as an in-patient or not, and they therefore have an enhanced prominence in the morbidity tables beyond their true importance; gonorrhoea, which supplies the majority of cases, has little need of inpatient treatment. The reduced importance of venereal diseases as a medical problem has been accompanied by shifts in the relative balance of types of infection. The Far East had a large proportion of chancroid, which was about a quarter of all cases in 1949, but dropped to a fifteenth by the end of our period. Even more interesting has been the changing ratio between gonorrhoea and nongonococcal urethritis, smear tests for which were almost always carried out. In the Far East, the ratio, which was about 3 to 1 soon after the war, fell to 1.7 in 1950 and 0.9 in 1956; while in Great Britain it was 2 to 1 soon after the war, falling to 1.3 in 1950 and 0.3 in 1956 . One might speculate whether the widespread use of penicillin for other purposes in the treatment of disease might have had a prophylactic effect upon the gonococcus; the difference between the theatres perhaps corresponding to different levels of protection in the host populations. At the same time no protection has been afforded against non-gonococcal urethritis. A similar fall is recorded in early syphilis, from 10 per cent. of the venereal diseases in the Far East soon after the war to 5 per cent. at the beginning of our period and 1 or 2 per cent. at the end; and in Great Britain from 19 per cent. soon after the war to 7 per cent. at the beginning of this period and 4 per cent. at the end.

Skin Diseases.-If the venereal diseases are excluded, the Far East rates were not so very much higher than those in the Middle East, the greatest excess being in skin conditions. These were of great importance in all commands, and were largely governed by the group of septic conditions such as boils and cellulitis, which averaged about 21 per 1,000 in the European commands and 32 per 1,000 in the tropical commands. The variation between years was higher in this particular case than between commands, in fact, a substantial decrease took place during the period, and the geographical variation was quite small at the end of it.

The principal addition in the Far East was from tinea, which was uncommon elsewhere but there reached the proportion of one-fifth of all skin conditions. Even this conceals its widespread extent, for large numbers who did not become in-patients were treated at medical centres as out-patients (if they had been documented in the same way as venereal diseases the latter would appear much less important). At the time of one investigation in the late summer of 1956, tinea pedis in the Far East was causing a first attendance at medical centres every week of one in fifty men. It was particularly prevalent in Malaya, although skin conditions as a whole seemed to be more frequent in Hong Kong. Presumably the local conditions of heat and damp, not to speak of operational needs, were responsible for the efflorescence of these complaints; it was shown in a trial of foot powders that the potential for tinea existed among reinforcements before the troops even reached the theatre. The evidence was that effective measures to deal with tinea pedis had to be considered in terms of hygiene rather than in terms of the chemical composition of a particular foot powder.

In the Middle East, where the heat is dry (and at times dusty), skin conditions were at their maximum from July to November, but even the month of lowest incidence (March) was only a fraction below the average. (The reference to dust may be misleading; the khamsin, the "50-day" sand wind, blows intermittently from March to May). This steadiness of incidence throughout the year appeared equally in Europe and at home, with only a slight rise in the autumn coinciding perhaps with manoeuvres.

Otitis Externa and Media.-Table II shows that a tropical climate, and particularly the Far Eastern one, also favours the onset of otitis externa and media, a group of diseases which should perhaps more properly be split so that the first is considered with the skin conditions, and the second with the throat infections. This is supported by the incidence rates (which are available separately only from 1952 onwards) shown in Table III.

TABLE III

AVERAGE ANNUAL ADMISSION RATES WITH OTITIS PER 1,000, 1952-1956

\begin{tabular}{|c|c|c|c|c|c|}
\hline \multirow{2}{*}{\multicolumn{4}{|c|}{ Command }} & \multicolumn{2}{|c|}{ Otitis } \\
\hline & & & & Externa & Media \\
\hline $\begin{array}{l}\text { UK } \\
\text { BAOR } \\
\text { MELF } \\
\text { FARELF }\end{array}$ & $\begin{array}{l}. . \\
\because\end{array}$ & $\begin{array}{l}. . \\
\because .\end{array}$ & $\begin{array}{l}. . \\
\because .\end{array}$ & $\begin{array}{l}1 \cdot 4 \\
1 \cdot 5 \\
4 \cdot 4 \\
8 \cdot 2\end{array}$ & $\begin{array}{l}3 \cdot 5 \\
3 \cdot 1 \\
4 \cdot 3 \\
5 \cdot 5\end{array}$ \\
\hline
\end{tabular}

Otitis media does not vary greatly between commands, but otitis externa, which is only half as extensive in the United Kingdom and Germany, is equally extensive in the Middle East, and almost double in the Far East. 
Respiratory Diseases.-The mention of throat infections in connexion with otitis media brings us to the consideration of respiratory conditions, which are shown in Table II to be as frequent as skin conditions. Their relative numerical importance depends on the definitions. Such comparisons can under-rate certain rarer diseases such as tuberculosis and rheumatic fever, which cause great wastage in terms of man-days. The groups used here for skin diseases and respiratory diseases are reasonably equivalent in this respect, since the average stay in hospital is about 11 or 12 days for each.

Streptococcal sore throat and scarlet fever have been omitted from the respiratory group, but their reported rates are low, perhaps in the former case because of the absence of a routine for isolating the organism. The respiratory diseases include five subgroups in order of rate:

\begin{tabular}{lllll}
\multicolumn{2}{c}{ Respiratory } & Diseases & \multicolumn{2}{l}{$\begin{array}{c}\text { International } \\
\text { List } \text { No. }\end{array}$} \\
\multicolumn{2}{c}{ Tonsillitis and Pharyngitis } &.. & $472-473$ \\
Common Cold &.. &. & 470 \\
Influenza &. &. & $\ldots$ & $480-483$ \\
Bronchitis &.. &. &. & $500-502$ \\
Pneumonia &.. &.. &.. & $490-493$
\end{tabular}

Table II shows that the United Kingdom is twice as vulnerable as elsewhere, but this is mainly due to the common cold and influenza. The rates of tonsillitis and pharyngitis in the Middle East are surprisingly high, of the same order as in Great Britain and

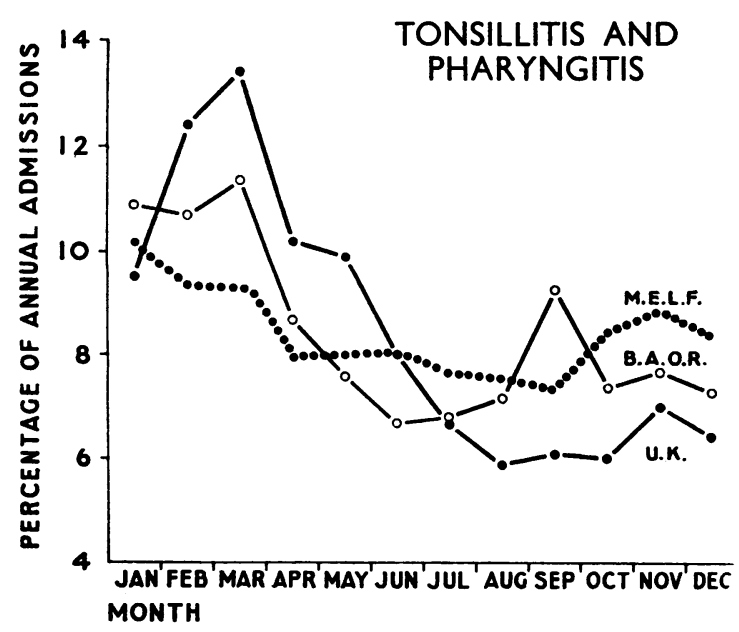

FIG. 2.-Monthly percentage of annual admission rates for tonsillitis and pharyngitis, averaged over $1950-1956$. (See Tables $N, O$, and $P$ of Appendix.) rather greater than in Germany, where the seasonal distribution is more similar to that of the Middle East than to that of the United Kingdom (where there is simply the expected winter peak), and has an additional peak in the late summer (Fig. 2). Once again, in the Middle East the khamsin has no apparent connexion in time which might implicate the excessive dust it raises as an irritant.

In the United Kingdom, the expected winter peak for tonsillitis and pharyngitis, already mentioned, is less pronounced than for other respiratory conditions. Influenza represents the most acutely epidemic form, concentrated often in one of the months between January and March, as for example in 1951, when half the year's total incidence was experienced in January; these first 3 months of the year account for two-thirds of the cases, and the period from May to September for only one-eighth. A study of the preceding monthly rates appears to afford no clue to the ensuing epidemic; probably a weekly return would be needed for this purpose. Common colds follow a modified version of the same seasonal pattern, and so also do bronchitis and pneumonia.

As one would expect, influenza fluctuates considerably from year to year, and causes a similar fluctuation in total disease rates. The pattern has been one of alternate high and low years, except for 1955 when an expected epidemic did not develop.

The importance of geographical variation has been so heavily stressed that it might be thought that within a country such as the United Kingdom, regional differences would be worth studying. The command structure is such that only two regions, Scottish Command and Northern Ireland District were reasonably distinct for our purposes. The other commands were Northern, with headquarters at York, Western with-headquarters at Chester, Eastern with headquarters at Hounslow and including the London area, and Southern with headquarters at Salisbury and including the Aldershot district. The difficulties arise from the mobility of troops in training, who may be located in one command while on the ration strength of another, and also from the specialist nature of some hospitals which attract patients from far and wide: this is of course a familiar and the most intractable problem of civilian hospital statistics. There is one saving possibility in the Army set-up as regards the minor forms of illness, which were likely to be dealt with locally. For instance, respiratory conditions were mainly treated in medical reception stations (where the average length of treatment was 6 days as compared with 25 days for hospitals). Therefore, if we confine ourselves to the widespread and less serious disease groups, we may hope to obtain comparable 
figures for the regions. As a basis we have used the number of injuries, the majority of which are not serious, and which there is no obvious reason to suppose should vary according to locality; such differences as do appear might be expected to reflect constant factors due to such administrative idiosyncracies as are mentioned above. On this basis of an annual rate of some 40 per 1,000 strength, we can erect a superstructure of other diseases as percentages in each area of the injury rate for the area. The result, in 1955 for instance, is to show, among the respiratory conditions, that tonsillitis and pharyngitis and bronchitis were comparatively steady as between regions, and that the greatest variation (relative to its numbers) occurred in cases of influenza, which were exceptionally numerous in Western Command, and were few in the North generally.

Other disease groups examined by the same method, which showed no exceptional variation between regions, were skin conditions, otitis externa and media, and the intestinal diseases.

Intestinal Diseases.-These have been of greatest concern in the Middle East (see Table II) where they dominated the medical scene from May till October, precisely the reverse of the United Kingdom with its ailments in winter, and its slackest month in August. (Germany had a more moderate winter peak, and also a rise at the end of the summer which might be ascribed to field training, when the intestinal diseases would be particularly prone to an increase).

The intestinal group is made up as follows:

\section{Intestinal Diseases}

$\begin{array}{lllll}\text { Enteric Fever } & \ldots & \ldots & \ldots \\ \text { Amoebiasis } & \ldots & \ldots & \ldots & \ldots \\ \text { Dysentery, other than Amoebic } & \ldots \\ \text { Diarrhoea, Enteritis, etc. } & \ldots & \end{array}$

Infective Hepatitis $\ldots \quad \ldots \quad$.

\section{International}

List No.

040-041

$045,047-048$

$785 \cdot 6,571-572$, 042,049

092
The largest and yet the mildest group was the somewhat amorphous one of "diarrhoea, etc." requiring an average treatment of about a week. A detailed examination of in-patient records shows that the great majority in the United Kingdom were diagnosed as gastro-enteritis and colitis, fairly evenly spread throughout the year, while in the Middle East this category was in a minority. The diarrhoea group may well include unidentified cases of dysentery. Bacillary dysentery was the other main or more specific contributor to intestinal disease in the Middle East, whereas amoebiasis was negligible, appearing rather in the Far East. The importance of the latter lay in its prolonged treatment of 5 or 6 weeks, as compared with 11 or 12 days for bacillary dysentery. Only a small proportion are recorded according to type, but among these it may be of interest to show the difference between countries in respect of Sonne dysentery and the Flexner-Boyd group. The following types were identified in 1953:

\begin{tabular}{lll|c|c}
\hline \multirow{2}{*}{ Command } & & \multicolumn{2}{c}{ Dysentery } \\
\cline { 3 - 5 } & & & Sonne & Flexner-Boyd \\
\hline UK &. &. & 17 & 3 \\
MELF & $\cdots$ &. & 43 & 116 \\
FARELF &.. &. & 5 & 56 \\
\hline
\end{tabular}

Sonne dysentery which is relatively important in the United Kingdom, takes a secondary place in the Middle East and is of relatively little importance in the Far East. The only other large group to be typed was Shiga dysentery (with seventeen cases in the Middle East and five in the Far East).

The United Kingdom cases of Sonne dysentery are too few to challenge the experience from civilian notifications of a maximum in March, but in the Middle East all forms of dysentery seem to increase in the summer. In this particular year Sonne dysentery had its maximum incidence in September, after an earlier outbreak in June; the Flexner-Boyd group was similar, but the unspecified forms of bacillary dysentery, which were about five times as large, had the June peak alone.

It may have been wrong to place infective hepatitis with this group, but at least it is clear from the admission rates that the disease is more common in the tropics than the temperate zones, and the same preventive sanitary measures are relied on to control it. A most interesting feature is that its seasonal occurrence lags behind that of the diarrhoea group 
in the Middle East and is high between September and January (Fig. 3).

We have kept to the end of this section on intestinal diseases the discussion on enteric fever, now fortunately of minor importance after its former pre-eminence, partly through treatment by chloramphenicol, but much more so by a reduction in incidence. It is the only one of the intestinal group against which protection is sought by the universal use of a vaccine, and possibly it is this which at times has brought it within bounds while the other intestinal diseases remained rampant. At any rate, by 1951 , it had reached a record low post-war level in the Middle East (there were too few cases elsewhere to be worth discussing). But now the position altered remarkably. The cases to date had been mainly typhoid, but in 1952 there was an outbreak in September, which brought the annual rate to about 4 per 1,000 , and proved to be paratyphoid $B$. Similar outbreaks occurred in subsequent years, and only began to decrease in 1955 when the evacuation of the Suez Canal Zone began.

The Middle East command has been particularly liable to changes in the location of troops, which can have the effect of greatly increasing the variation in

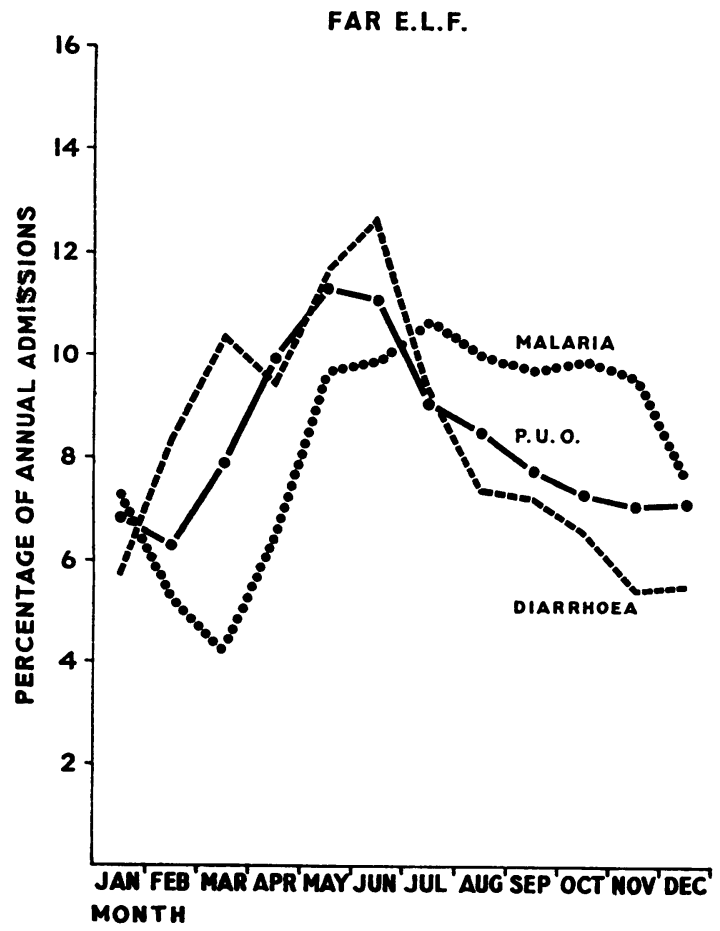

disease rates. It is an enormous and heterogeneous area, at one time including East Africa and Mauritius, which were, however, separated off in 1953. Malta was also separated at the end of that year, and in 1955 the Sudan was evacuated; few troops had indeed been stationed in the Sudan, but they had a particularly high sickness rate. The sick rate of the whole command was largely determined until 1955 by the troops in the Canal Zone, where the rate was generally lower than elsewhere. When the Suez evacuation was completed in 1956, Cyprus grew correspondingly in importance, as headquarters of the command.

No other command had the composition of its forces shifted around to the same extent during this period. Troops were withdrawn from Trieste in 1954, and from Austria in 1955, but these do not come under discussion as they were never in BAOR. The only other change to affect this survey was the inclusion in FARELF, half-way through 1956, of the troops that remained in Korea.

Malaria.-This is mainly a problem in the Far and Middle East. Elsewhere in the world where British troops have been stationed recently, the only

Fio. 3.-Monthly percentage of annual admission rates for pyrexia of unknown origin, diarrhoea, and malaria, averaged over $1950-1956$. (See Tables $\mathbf{P}$ and $\mathbf{Q}$ of Appendix.) 
place with higher rates has been West Africa (which otherwise has become surprisingly healthy when compared with former standards).

The malaria position in the Far East has been improving ever since it was brought under control towards the end of the second world war. In the period under review, paludrine (proguanil) was used as a prophylactic. That it did not eradicate malaria completely is evident from the cases occurring in the United Kingdom among returning soldiers; some also were found among Reservists called up for annual training. In certain years, for instance 1952 and 1953, as many cases were being discovered in the United Kingdom as in the Far East. (The numbers truly "at risk" of course were far from being the strength of the United Kingdom.) The relapses were almost all cases of the benign tertian variety (B.T.), and in the Far East these comprised two-thirds of the cases, the remainder being accounted of the malignant tertian variety (M.T.). This is presumably because of the fact, known from the action of the drug, that paludrine is a true causal prophylactic for M.T. malaria, but merely suppresses B.T. malaria. In contrast to the Far East, the malaria in West Africa was largely of the malignant tertian variety.

Pyrexia of Unknown Origin (P.U.O.).-This is the residue of the once enormous fever group that has been progressively reduced as the discovery of particular organisms, carriers, or modes of transmission, have enabled distinctive labels to be given to fevers of various kinds. Many of those remaining must be merely mild, and therefore clinically unrecognized, cases of known diseases, which perhaps do not justify a detailed laboratory investigation to establish their origin. In recent times leptospirosis and scrub typhus have been suggested as accounting for some of the cases, but it seems at present that no single cause is going to allow for the dramatic renaming of the whole group, and that a variety of agents contribute to it. It is worth adding a remark about the seasonal distribution, since that can be looked for to provide an epidemiological clue. In the Far East, averaged over the years, the peak period for P.U.O. appeared to be in the early summer-roughly the same distribution indeed as the diarrhoea group, whereas malaria had a much later maximum. In the Middle East, P.U.O. is at its highest later in the summer, about the same time also as the intestinal group (Fig. 3).

Appendicitis and Peptic Ulceration.-The Morbidity Tables in the Appendix, which give fuller details of the diseases that have been discussed above in outline, also cover a few conditions such as appendicitis which are of comparatively small importance individually, and are not, as are the infections, potential sources of epidemics. They nevertheless take their regular toll among young soldiers.

Details obtained from in-patient records show that the great majority of appendicitis cases were acute, but an interesting feature of the remainder, including those of chronic appendicitis, was that they contain a higher proportion of officers, even at comparable ages. In acute appendicitis there was no apparent distinction between officers and other ranks, both having a reduced incidence with advancing age. As to appendicectomies, 3,256 were performed in the United Kingdom in the 3 years from 1952 to 1954, out of 3,960 cases (82 per cent.).

The cases of appendicitis which were reported on the monthly returns exceeded by a quarter those for which in-patient records were eventually received, and although a similar position holds for other diseases, this may be invoked to explain the following diagnostic conundrum. It was noted in the Report on the Health of the Army for 1951 and 1952 (1954) that a correlation in time appeared to exist between appendicitis and peptic ulcers (actually duodenal ulcers) since 1945 , both having increased while the general tendency in other diseases, was to a decrease. (This correlation is not apparent from the Appendix Tables, as it depends more on the earlier post-war years.) The suggestion was that an illdetermined pain might be given a provisional diagnosis, indiscriminately between the two, and might clear up without confirmation. An aid to this might certainly be the age of the patient, for peptic ulceration is not a disease of young soldiers as is appendicitis.

\section{The INfluence of Age}

Although it was established at the beginning that age was of little account in examining time trends of morbidity among young soldiers, and was much less important than a geographical distinction, this is not to deny that age constitutes one of the prime factors in the epidemiology of the subject. Already we have had to refer once or twice to situations where the young soldier has a very different sickness experience from the rest of the Army, and sometimes this is so marked that it is noticeable even within the very small range covering the ages that we mean by the term young soldier (i.e. the National Service range, which is certainly under 30 years).

The remainder of this review is based on analyses of in-patient records which give more detail than the monthly returns, but for various reasons add up to 
smaller totals, and therefore should not be compared directly with the rates already quoted. They may be relied on rather as local indices, giving a trustworthy comparison within their own sphere, for example, between age groups.

In the United Kingdom the highest admission rates were undoubtedly in the youngest age group, reflecting the position with respiratory diseases and others. If we take the standard 5-year age groups, the youngest (up to 19 years on his last birthday, i.e. less than 20 years old) is in reality a two-year group only, with few under the age of 18 . The four groups over the age of 30 are not within the definition of a young soldier but may indicate occasionally the ultimate drift. Overseas the youngest group of all did not always have the highest sickness experience. This is exaggerated by venereal diseases which reach a peak in the twenties, but there remains a slight difference without them, as shown in Fig. 4, which also indicates the rapid falling off in rates after the age of 30 .

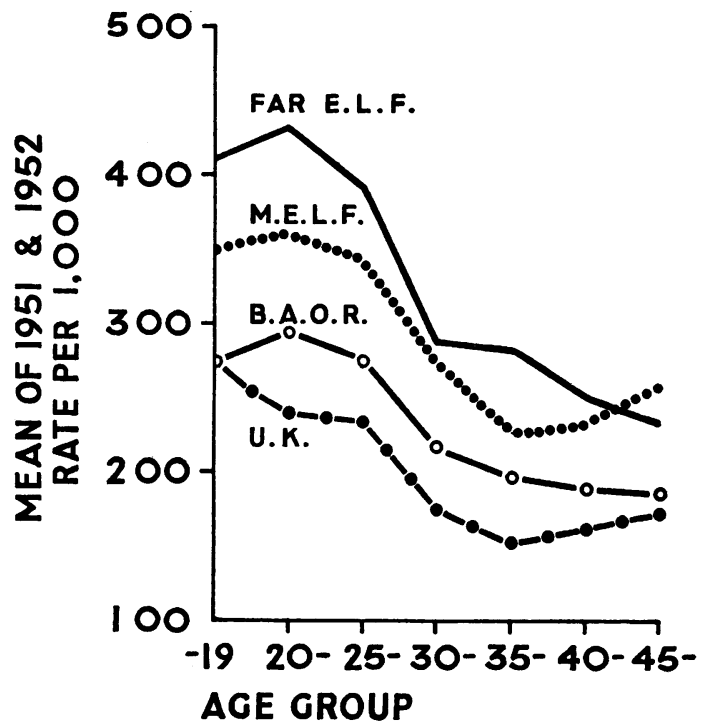

FIG. 4.-Average admission rates for all causes less venereal diseases, by age, 1951-1952. (See Table IV.)

Fig. 4 is based on Table IV, which relates to 1951-1952.

TABLE IV

ADMISSIONS FOR ALL CAUSES LESS VENEREAL DISEASES AVERAGE RATES FOR 1951-1952 PER 1,000 STRENGTH, BY AGE LAST BIRTHDAY

\begin{tabular}{ll|c|c|c|c|c|c|c}
\hline \multicolumn{2}{c|}{ Age (yrs) } & -19 & $20-24$ & $25-29$ & $30-34$ & $35-39$ & $40-44$ & $45-$ \\
\hline UK & $\cdots$ & 272 & 244 & 238 & 176 & 151 & 160 & 172 \\
BAOR & $\cdots$ & 270 & 295 & 278 & 216 & 195 & 186 & 185 \\
MELF & $\cdots$ & 349 & 355 & 338 & 277 & 228 & 232 & 260 \\
FARELF & $\cdots$ & 414 & 432 & 396 & 295 & 285 & 256 & 231 \\
\hline
\end{tabular}

In spite of the marked age contrast, the previous discussions on the basis of total rates remain valid owing to the preponderance in strength at the younger ages.

The unexpectedly lower rate of the youngest group overseas may have been partly due to their more recent embarkation, considered as a group, having passed a fitness test on leaving the United Kingdom. To heighten the contrast, the youngest group in the United Kingdom would have the greatest share of recruits suffering from the newly-encountered hazards of military life. One fairly obvious contribution would come from the effects of being inoculated: this is reflected in the injury figures, and together with the large number of injuries sustained during sport for all young soldiers explains the similar and even sharper contrast with the older soldiers than is evident in the Table of admissions for all causes. (See Appendix Table R which shows admissions for injuries and certain diseases by age.) The presence of recruits in the United Kingdom during their first months of service tends to weight the youngest age group of all, so that it is centred at a rather lower age than overseas.

The infectious diseases of childhood naturally diminished with age in the combing out of the last few who were not immune; rubella, for instance, claimed no victims after the age of 30 . But similar steep trends (not however leading to complete disappearance) were evident with the acute respiratory conditions and skin diseases. With these (Fig. 5, opposite), the age effect was powerful enough to overcome any such tendency as that noted above in all causes for the very youngest group overseas to have a slightly lower rate; in any case, being fit enough to go overseas would be no guarantee against getting tonsillitis or tinea or a great number of other complaints.

It would appear from the graph of the respiratory conditions, that the excess in the United Kingdom is greater in the younger age groups. As noted above, the excess can be accounted for most aptly by influenza and the common cold. The skin conditions in Fig. 5 tell a similar story in regard to the Far East, and here it is tinea that accounts for the excess most satisfactorily. A recent arrival in the Far East corresponds possibly to a recruit in the United Kingdom, and the former in spite of physical fitness was susceptible to new kinds of infection. Actually tinea does not get a hold until the third or fourth month, as seen from Table V (opposite).

(The next section includes a discussion of roundingup errors in length of service, which applies here too.) 

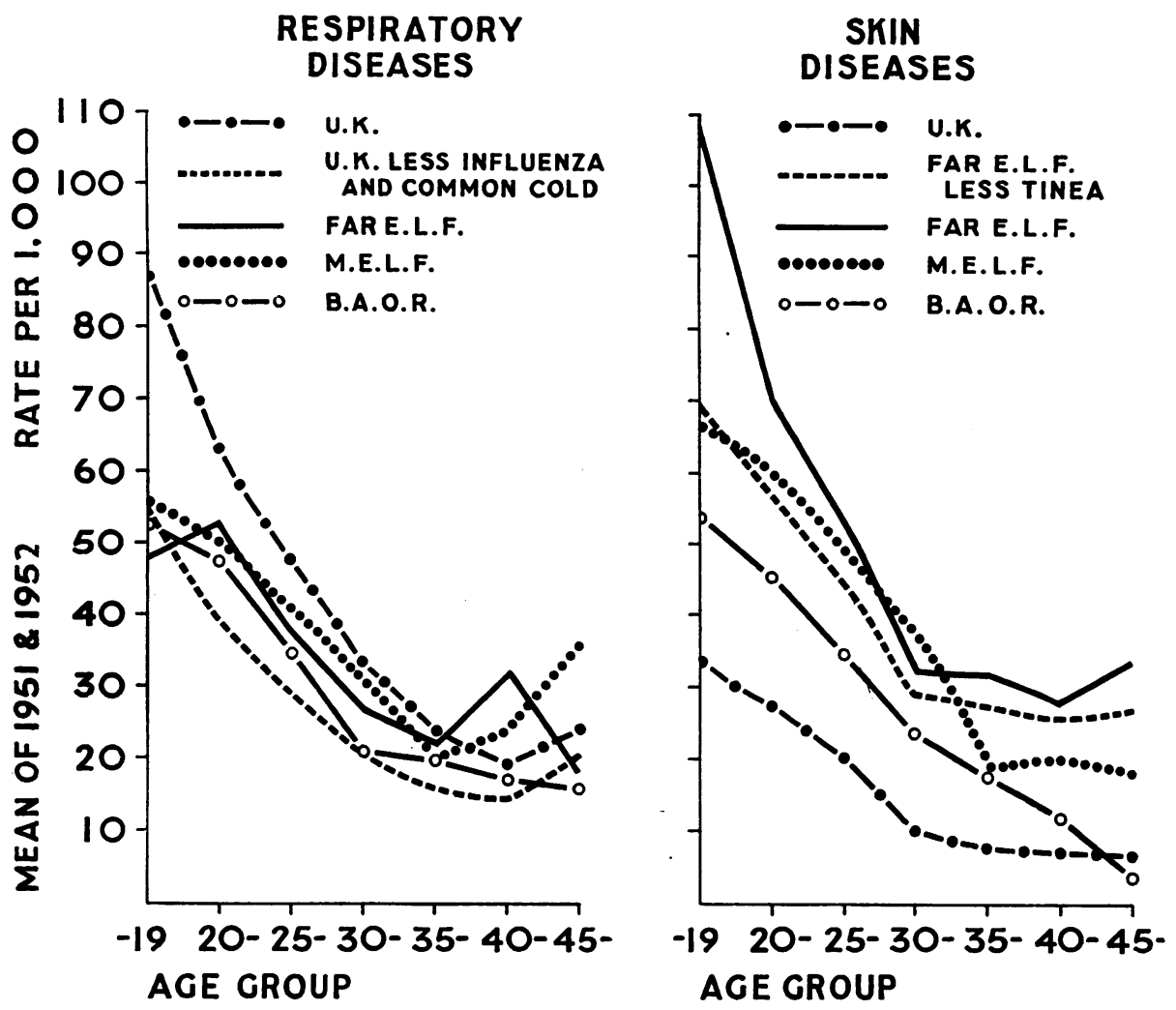

Fig. 5.-Average admission rates for respiratory diseases and skin diseases, by age, 1951-1952. (See Table R of Appendix.)

TABLE V

ADMISSIONS FOR SKIN DISEASES, FARELF 1954, AMONG NATIONAL SERVICEMEN, BY MONTHS SINCE ARRIVAL IN THEATRE, FOR FIRST 6 MONTHS

\begin{tabular}{c|c|c}
\hline $\begin{array}{c}\text { Completed Months } \\
\text { in Theatre }\end{array}$ & Tinea & Other Skin Diseases \\
\cline { 2 - 3 } & 4 & 33 \\
1 & 7 & 50 \\
2 & 22 & 41 \\
3 & 44 & 61 \\
4 & 49 & 47 \\
5 & 29 & 51 \\
\hline
\end{tabular}

Some types of risk were only indirectly related to age, such as the risk of malaria, which was greatest in the areas where mosquitoes were not under control, that is the areas of active patrolling. The members of the patrols would very likely consist of young soldiers, but would include only those who had had an initial period of acclimatization and training after arrival in the theatre. This factor may have been at work in some components at least of P.U.O., which we last spoke of as having, in the Middle East, a seasonal picture like that of the intestinal diseases. Fig. 6 (overleaf) shows that there is an age difference in respect of the youngest group, who seemed to be particularly liable to attacks of diarrhoea and dysentery (and incidentally also of enteric fever) on arrival in the Middle East, but who suffered less excessively from P.U.O.

Table VI shows how immediate was the onset of diarrhoea on arrival in the Middle East. (Again some correction may be needed for rounding-up errors.)

\section{TABLE VI}

ADMISSIONS FOR DIARRHOEA AND ENTERITIS, MELF AMONG NATIONAL SERVICEMEN, BY MONTHS SINCE ARRIVAL IN THEATRE, FOR FIRST 6 MONTHS

\begin{tabular}{c|c}
\hline Completed Months in Theatre & Diarrhoea and Enteritis \\
\hline 0 & 86 \\
1 & 87 \\
2 & 77 \\
3 & 57 \\
4 & 60 \\
5 & 46 \\
\hline
\end{tabular}




\section{PYREXIA OF UNKNOWN ORIGIN}

INTESTINAL DISEASES
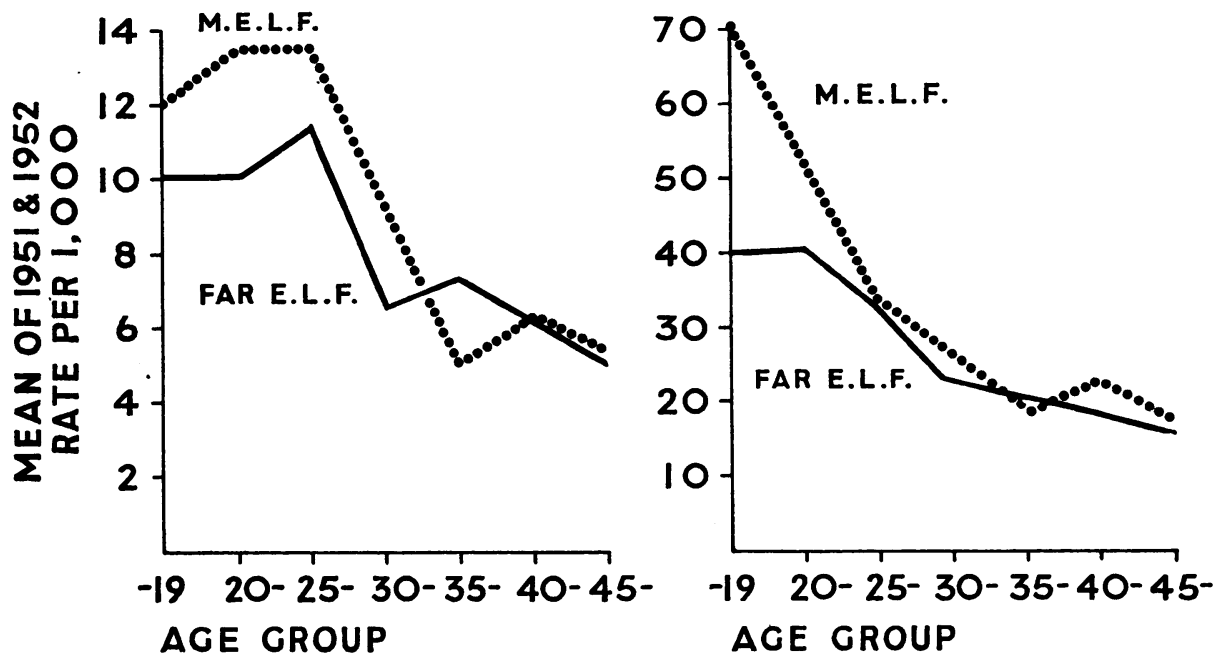

FIG. 6.-Average admission rates for pyrexia of unknown origin and intestinal diseases, by age, 1951-1952. (See Table $R$ of Appendix.)

The seasonal occurrence of infective hepatitis, which was provisionally included in the intestinal group, was found to lag a few months after the rest of the group in the Middle East. The age of maximum incidence was the early twenties, not the under twenties as with diarrhoea and dysentery, and there is therefore a suggestion that a time delay exists, while the infective organism is being harboured before the appearance of clinical signs.

\section{LENGTH OF SERVICE}

Age and service are the warp and weft of disease in the Army, and it will become plain in the sequel that among National Servicemen the weft has created the pattern of the material, as in a tapestry pattern.

A consideration of the different lengths of service of cases admitted reveals a spectacular concentration in the early months of service, among those treated in the United Kingdom. Table VII shows the relative percentages in 1952, as stated by the patient. A closer investigation of periods such as "a month's service" proves that this is liable to rounding-up errors. A detailed investigation was made of a sample of respiratory conditions, which bulked largely in these admissions. The proportion of corrected statements might conceivably vary in a particular disease with an unusual service distribution, but for the present purpose the correction is adequate, and puts the percentage in the first monthe up to 17 per cent. with compensating corrections subsequently. Injuries have been omitted from Table VII in order to exclude the effects of inoculation; which would have emphasized the early months even more.

\section{TABLE VII}

PERCENTAGE NATIONAL SERVICEMEN ADMITTED TO MEDICAL UNITS IN THE UK, ALL DISEASES, 1952, BY COMPLETED MONTHS OF SERVICE

\begin{tabular}{c|c}
\hline Completed Months of Service & As Stated by Patient \\
\hline 0 & $10 \cdot 4$ per cent. (corrected \\
to 17 per cent. for \\
rounding-up errors) \\
1 & $13 \cdot 3$ \\
2 & $9 \cdot 5$ \\
3 & $8 \cdot 5$ \\
4 & $6 \cdot 6$ \\
5 & $5 \cdot 3$ \\
$6-8$ (3-mth average) & $4 \cdot 6$ \\
$9-11$ (3-mth average) & $2 \cdot 4$ \\
$12-17$ (6-mth average) & $2 \cdot 0$ \\
$18-23$ (6-mth average) & $2 \cdot 2$ \\
\hline
\end{tabular}

The apparent effect of length of service is exaggerated in Table VII, since the numbers at risk in the United Kingdom diminished after about 4 months owing to service overseas; by the second year, half would be overseas. (A global analysis would not help greatly as the disease risk varies so much from that experienced in the United Kingdom.) Even so, the general trend can be 
demonstrated with a stabilized rate after about the ninth month and throughout the second year; the initial rate of sickness is certainly three times as great as that in the later period.

As to the cause, the subjection to a strange environment and exposure to infection would seem sufficient; much of the trend can certainly be ascribed to respiratory conditions. Another factor may be the admission of some patients to hospital before discharge from the Army on medical grounds which were only discovered at the call-up examination (many such rejections, however, would be treated as out-patients).

Although there is really no gainsaying the first 3 months' experience, when the recruit is receiving his primary training, the question arises whether the apparent effect of service is a mere by-product of increasing age, or whether the converse is true, that an apparent improvement with age is merely a reflection of long service. The two are difficult to disentangle, since generally speaking the older soldier has the longer service. So far we have as it were looked at the edges of the penny (a straight line from any direction) but not down on its face.

The problem was insoluble for a long while, for although each in-patient record could provide the information about both age and service, the numbers at risk for every combination of values of age and service were not known. This problem was eventually solved by obtaining a random sample of the Army which gave the required information. The cases could then be related to an appropriate number at risk, scaled up to a correct total for the actual size of the Army. The error in each rate so calculated is larger than that usually assumed in evaluating morbidity rates because the denominator is in fact based on a small sample; standard errors have therefore been calculated to take account of the extra uncertainty thus introduced, and are quoted in the tables. Table VIII, for example, gives the rates for all diseases in the United Kingdom in 1954. (The

TABLE VIII

ALL DISEASES AMONG NATIONAL SERVICEMEN IN U.K., 1954

Rates per 1,000 , by age and length of service

\begin{tabular}{c|c|c|c}
\hline \multirow{2}{*}{ Age Last Birthday (yrs) } & \multicolumn{2}{|c|}{ Length of Service (completed months) } \\
\cline { 2 - 3 } & 0 & $3-$ & $12-$ \\
\hline Up to 18 & $* 290 \pm 45$ & $* 313 \pm 52$ & - \\
\hline 19 & - & $134 \pm 21$ & $198 \pm 28$ \\
\hline 20 and Over & $268 \pm 55$ & $173 \pm 27$ & $* 98 \pm 10$ \\
\hline
\end{tabular}

* Rates which depart significantly from the average in an overall numbers at risk are strictly appropriate to 1955 , when the sample was actually taken.)

Owing to the small numbers with a year's service who were yet under 19 years of age, these have teen grouped with those over 19. There were also few aged 19 with less than 3 months' service (deferment being usually for 2 years), and these have been grouped with those over 20 years old. Admittedly the groups do not fall neatly into the cells allotted in the Table, and this leads to some surprising results. The reason is that cells in a particular column have different centres of gravity. For example in the last column, showing those in their second year of service; the average service for those aged 19 was 1 year 4 months, while for those aged 20 and over it was 1 year $7 \frac{1}{2}$ months. Similarly, for those in their first year of service, after the primary recruit stage (i.e. the centre column), the average service for those below the age of 19 was 5 months, for those aged 19 it was $8 \frac{1}{2}$ months, and for those aged 20 and over it was $7 \frac{1}{2}$ months. From the point of view of age, that is to say the rows of the Table, there is little in it; the recent recruits aged 20 and over have an average age of 21 , and the remainder an average age of 22 .

Although it is possible to compare pairs of these rates in the ordinary way, an overall test is very revealing, as a first step, and we find the following significant departures from the average:

The rate for those aged 20 and over in their second year of service is significantly low, and the rates for those under the age of 19 (both recent recruits and others still in their first year of service) are significantly high. (The recent recruits aged 20 and over are fewer than those aged 18, and the rate is therefore less easily demonstrated as significant.) There is agreement here with the conclusion already reached tentatively that the first months have an exceptionally high rate, particularly if we remember that the average service in the top cell of the centre column is only 5 months compared with 8 months lower down. Now, however, the effect is seen in relation to age, and estimates of the rates are provided in detail at various age and service intersections. It can be seen how the age taken by itself will provide a marginal picture of steadily decreasing rates; the averages of Table VIII weighted according to the numbers at risk are as follows:

\begin{tabular}{c|c}
\hline Age (yrs) & Rate per 1,000 \\
\hline Up to 18 & 297 \\
19 & 176 \\
20 and Over & 127 \\
\hline
\end{tabular}


In the same way the marginal rates for different lengths of service are:

\begin{tabular}{c|c}
\hline Months of Service & Rate per 1,000 \\
\hline $0-$ & 278 \\
$3-$ & 199 \\
$12-$ & 133 \\
\hline
\end{tabular}

Yet from Table VIII the true picture is more circumstantial. To start with we can only deduce the effect of long service for anyone aged 18, or initial service for anyone aged 19. However, the latter point is easily acceptable, because both younger and older National Servicemen have a high rate in the first 3 months. As for longer periods of service, the evidence for the second year having a lower rate is confined to those aged 20 and over. The difference for those aged 19 is not significant, and it is noteworthy that the interval in this case is only $7 \frac{1}{2}$ months as compared with a year for the older group.

From the other point of view, looking for an effect of age at equivalent lengths of service, we must make some allowance for the differing centres of gravity already discussed, but even so there seems to be a higher sickness rate for those aged 18 in their first year of service (after primary training), and for those aged 19 in the second year, that is to say a true effect of age making for greater liability to sickness in the younger recruit, while in the first three months of service there is no detectable trend for age. The phrase "true effect of age" is still not an irreducible biological finding, since it is confounded with the deferred status of the older recruits, so that the latter may come from a healthier section of the population (they have been shown (Rosenbaum, 1954) to differ in physique). The expectation with a later call-up for everyone would be that a slightly lower sickness rate would result from the entry of fewer who were still not immune to the adolescent infections, but that the same pattern would remain of a distinction between the deferred and other National Serviceman.

A similar story can be told with regard to individual diseases, but these are more appropriately dealt with in special studies; for example, respiratory diseases whose major contribution to the pattern was mentioned earlier. One important group may be put forward here as a specimen, namely skin conditions, which are given in Table IX in the same form as for all diseases.
TABLE IX

SKIN CONDITIONS AMONG NATIONAL SERVICEMEN IN U.K., 1954

Rates per 1,000 , by age and length of service

\begin{tabular}{c|c|c|c|}
\hline \multirow{2}{*}{ Age Last Birthday (yrs) } & Length of Service (completed months) \\
\hline Up to 18 & 0 & 3 & $12-$ \\
\hline 19 & $33 \cdot 0 \pm 5 \cdot 3$ & $* 43 \cdot 0 \pm 7 \cdot 3$ & - \\
\hline 20 and Over & $34 \cdot 7 \pm 7 \cdot 3$ & $21 \cdot 1 \pm 3 \cdot 5$ & $* 13 \cdot 1+1 \cdot 5$ \\
\hline
\end{tabular}
est.

The same provisos apply to Table IX as to Table VIII, and the same deductions can be made with one exception. Tables VIII and IX are in fact practically proportional to one another throughout in the ratio $1: 7 \frac{1}{2}$, except that the high incidence among the young recruits is less pronounced for skin conditions than for diseases in general.

Having shown that length of service is of prime importance for the incidence of disease among National Servicemen, it is necessary to remark that the age span used as a contrast is a narrow one. Age differences of the order of 10 or 20 years are of course as important in the trained soldier as amons civilians.

\section{THE SOLDIER's JoB}

Occupation is a standard axis of classification in morbidity and mortality studies, and in national comparisons it is wisest perhaps to stick to a single appelative, and to describe the occupation of the National Serviceman as just "soldiering". This covers such a multitude of occupational risks that it is not easy to obtain clear facts on them severally. The classical approach in the Army has been to look for officer differences and for differences between Corps, but these are difficult to interpret. For instance officers are older on average than other ranks and can be expected to share the lower sickness rates of the older groups. (In a survey of National Servicemen, officers play a much smaller part, being a smaller fraction, than in the remainder of the Army. They are older than other National Servicemen, and it is likely that they enjoy the same sort of background advantage in respect of health that the deferred men do.) As to differences between Corps, this was once justified on the grounds of certain stations being unhealthy, together with long periods of sojourn in them. Now there is not the same degree of permanence, and hygiene practice is universal and thorough. This is reflected in the sameness of many disease rates as far as they have been examined 
(excluding injuries) and there is usually ample explanation for crude (that is not standardized) differences in the different age structures and proportion of National Servicemen; occasionally no doubt there is an exception, as with the greater liability of the Royal Army Medical Corps before 1953 to contract cases of tuberculosis (a distinction once upon a time credited to the Guards, perhaps because of their barracks which were situated in London. This distinction no longer holds). The chief difficulty in making comparisons between Corps is that they do not start level in respect of their physical condition. For instance, the Infantry would accept only Grade I men, and Grade III men would be assigned to the few Corps which could make use of them, with their restricted liability to serve say on lines of communication or in the United Kingdom only. Such evidence as there is points to a higher sick rate for these Grade III men.

Injuries were excluded from the comments above, because there at least the Corps breakdown is a revealing one. Revealing, that is, in the sense of providing estimates, for there is nothing very unexpected about some of the results. Cooks tend to get scalded, and infantry to become battle casualties. But, with injuries as with diseases, a large proportion of the time at risk was spent on activities common to all soldiers, and under the same aegis of the Army Council, with its meticulous and almost grandmotherly concern for every detail of a soldier's existence, and its equitable distribution of the necessities of life and health.

The key factors of geography and of length of service were associated inevitably with a soldier's occupation. He was certain to do his primary training in the United Kingdom, and then stood an even chance of going abroad, perhaps to engage in advanced training and no more (BAOR), or to do jungle patrolling in Malaya and risk the tropical diseases, or even to fight in a formal war as in Korea. The accidents of contemporary history were superimposed on the more permanent features of climate, vectors, and the indigenous minusculae, to aggravate the consequences in terms of disease.

The great majority however were in non-operational roles, and particularly in the case of the young soldiers led a life which differed in well-known respects from the civilian norm. With inevitable exceptions, they lived in barracks or huts and slept in dormitories, ate in communal dining-rooms, spent a deal of time out of doors, were frequently inspected, and had their illnesses promptly attended to. In their first 3 months of service they were congregated in barracks with other recruits of a like junior status, but subsequently joined a Service unit with a crosssection of age and experience.

\section{MORTALITY}

We have covered in the discussion of separate disease and injury groups some half to two-thirds of all admissions to medical units. Serious as they are from the point of view of the Army health authorities they do not have the same immediate concern for the individual; they are not identical with the fatal diseases. Something should be said on this score, although the number concerned was small, being of the order of 1 per 1,000 per year, apart from deaths in action.

A comparison between theatres is of little use, since many seriously ill patients were evacuated to the United Kingdom and died there (determining the theatre where the disease originated is a difficult matter); in addition certain cases would have been detected before leaving for an overseas tour of duty, and the populations at risk overseas were selected groups from the point of view of fitness. (A similar consideration applies to morbidity, but here the effect is of far less importance except in a few instances, for example tuberculosis.) Deaths are therefore to be thought of in relation to the Army as a whole, with the one notable exception of deaths due to injury, which outnumbered those due to all the diseases put together. Death due to injury is exceptional in that the cause is usually immediately related to the sequel. The result is that three deaths from injury occurred overseas for every one at home, although the numbers at risk were about equal. (This allows for deaths due to enemy action. It should be noted that the deaths due to enemy action shown in Table $M$ of the Appendix, only include those which occurred in a medical unit and cases in which a body was brought in already dead. Other cases of death in action are not included.)

The more important of the diseases causing death are listed in Appendix Table $\mathbf{M}$; the inclusion of older men is less justified in an appraisal of young soldiers. Movements in time are none the less reflected well enough, and the tremendous reduction in deaths from tuberculosis is shown to have begun in 1949, to 1950. The fall appeared to be far steeper than among civilians, which might have been partly due to the policy of discharging patients to civilian sanatoria before the disease had taken its full course. 


\section{SUMmary}

A review has been made of the health of young soldiers over a 7-year period, from 1950 to 1956, when the conditions of National Service and the structure of the Army were fairly stable. It is pointed out that National Service covered the fittest 80 per cent. of the young male population of the country (the Army took over two-thirds of them), and that the consequences of soldiering were therefore important to the health of the nation.

Geographical and climatic differences in the places where they served were found to have greater influence on their health during the period studied than differences from year to year, although decided improvements were recorded between the beginning and end of the 7 years under review.

Certain diseases could always be associated with particular theatres, such as intestinal diseases in the Middle East, skin diseases in the Far East, and respiratory diseases in the United Kingdom.
Age was a subordinate factor in the United Kingdom in determining morbidity, which was shaped largely by length of service, the recruit stage being particularly vulnerable in respect of respiratory conditions. A similar factor came into play on being exposed to another new environment after arrival in the tropical commands.

Such advantage as there appeared to be in a later call-up was probably due in the main to the healthier home background of those whose service had been deferred.

\section{REFERENCES}

Mackay, D. (1951). "Hospital Morbidity Statistics", G.R.O. Studies on Medical and Population Subjects, No. 4. H.M.S.O., London.

Report on the Health of the Army for 1951 and 1952 (1954). By command of the Army Council. (W.O. Code No. 11055).

Report on the Health of the Army for 1954 (1958). By command of the Army Council. (W.O. Code No. 11709).

Rosenbaum, S. (1954). J. roy. statist. Soc., Series A, 117, 331.

\section{APPENDIX TABLES}

APPENDix TABLe A

ADMISSIONS OF BRITISH ARMY MALES IN MAIN COMMANDS, 1950-1956 RATES PER 1,000 STRENGTH, ALL DISEASES

\begin{tabular}{|c|c|c|c|c|c|c|c|c|c|c|c|c|}
\hline \multicolumn{4}{|c|}{ Command } & 1950 & 1951 & 1952 & 1953 & 1954 & 1955 & 1956 & Average & Range \\
\hline $\begin{array}{l}\text { UK } \\
\text { BAOR } \cdots \\
\text { MELF } \\
\text { FARELF }\end{array}$ & $\begin{array}{l}\ddot{*} \\
\ddot{\cdots}\end{array}$ & $\begin{array}{l}\ddot{ } \\
\ddot{*} \\
\ddot{*}\end{array}$ & $\begin{array}{l}\cdots \\
\cdots \\
\cdots\end{array}$ & $\begin{array}{l}275 \cdot 7 \\
309 \cdot 7 \\
420 \cdot 4 \\
614 \cdot 4\end{array}$ & $\begin{array}{l}281 \cdot 8 \\
300 \cdot 9 \\
402 \cdot 8 \\
568 \cdot 8\end{array}$ & $\begin{array}{l}274 \cdot 2 \\
227 \cdot 6 \\
357 \cdot 5 \\
459 \cdot 1\end{array}$ & $\begin{array}{l}303 \cdot 0 \\
240 \cdot 6 \\
333 \cdot 0 \\
416 \cdot 5\end{array}$ & $\begin{array}{l}251 \cdot 3 \\
214 \cdot 2 \\
254 \cdot 5 \\
418 \cdot 7\end{array}$ & $\begin{array}{l}226 \cdot 9 \\
217 \cdot 4 \\
263 \cdot 2 \\
338 \cdot 8\end{array}$ & $\begin{array}{l}213 \cdot 4 \\
175 \cdot 8 \\
271 \cdot 2 \\
387 \cdot 1\end{array}$ & $\begin{array}{l}260 \cdot 9 \\
240 \cdot 9 \\
328 \cdot 9 \\
457 \cdot 6\end{array}$ & $\begin{array}{r}89 \cdot 6 \\
133 \cdot 9 \\
165 \cdot 9 \\
275 \cdot 6\end{array}$ \\
\hline Range . . & $\ldots$ & $\ldots$ & $\ldots$ & $338 \cdot 7$ & $287 \cdot 0$ & $231 \cdot 5$ & $175 \cdot 9$ & $204 \cdot 5$ & $121 \cdot 4$ & $211 \cdot 2$ & & \\
\hline
\end{tabular}

APPEndix TABle B

ADMISSIONS OF BRITISH ARMY MALES IN MAIN COMMANDS, 1950-1956 RATES PER 1,000 STRENGTH ALL INJURIES

\begin{tabular}{|c|c|c|c|c|c|c|c|c|c|c|c|c|}
\hline \multicolumn{4}{|c|}{ Command } & 1950 & 1951 & 1952 & 1953 & 1954 & 1955 & 1956 & Average & Range \\
\hline $\begin{array}{l}\text { UK } \\
\text { BAOR }\end{array}$ & $\begin{array}{l}\ddot{*} \\
\ddot{*}\end{array}$ & $\begin{array}{l}\cdots \\
\cdots \\
\cdots\end{array}$ & $\begin{array}{l}\cdots \\
\cdots \\
\cdots\end{array}$ & $\begin{array}{l}34 \cdot 7 \\
61 \cdot 1 \\
40 \cdot 3 \\
59 \cdot 5\end{array}$ & $\begin{array}{l}32 \cdot 6 \\
59 \cdot 2 \\
40 \cdot 4 \\
54 \cdot 2\end{array}$ & $\begin{array}{l}32 \cdot 6 \\
52 \cdot 8 \\
41 \cdot 1 \\
51 \cdot 2\end{array}$ & $\begin{array}{l}34 \cdot 7 \\
55 \cdot 1 \\
38 \cdot 8 \\
57 \cdot 0\end{array}$ & $\begin{array}{l}34 \cdot 8 \\
53 \cdot 1 \\
29.6 \\
50.9\end{array}$ & $\begin{array}{l}37 \cdot 9 \\
58 \cdot 5 \\
34 \cdot 7 \\
48 \cdot 6\end{array}$ & $\begin{array}{l}42 \cdot 6 \\
55 \cdot 7 \\
56 \cdot 1 \\
55 \cdot 8\end{array}$ & $\begin{array}{l}35 \cdot 7 \\
56 \cdot 5 \\
40 \cdot 1 \\
53 \cdot 9\end{array}$ & $\begin{array}{r}10 \cdot 0 \\
8 \cdot 3 \\
26 \cdot 5 \\
10 \cdot 9\end{array}$ \\
\hline Range .. & $\ldots$ & $\ldots$ & $\ldots$ & $26 \cdot 4$ & $26 \cdot 6$ & $20 \cdot 2$ & $22 \cdot 3$ & $23 \cdot 5$ & $23 \cdot 8$ & $13 \cdot 5$ & & \\
\hline
\end{tabular}


APPendix TABle C

ADMISSIONS OF BRITISH ARMY MALES IN MAIN COMMANDS, 1950-1956 RATES PER 1,000 STRENGTH, RESPIRATORY DISEASES

\begin{tabular}{|c|c|c|c|c|c|c|c|c|c|c|c|c|}
\hline Int. List & Disease & \multicolumn{2}{|c|}{ Command } & 1950 & 1951 & 1952 & 1953 & 1954 & 1955 & 1956 & Average & Range \\
\hline \multirow[t]{2}{*}{$472-473$} & \multirow[t]{2}{*}{$\begin{array}{c}\text { Tonsillitis and } \\
\text { Pharyngitis }\end{array}$} & $\begin{array}{l}\text { UK } \\
\text { BAOR. } \\
\text { MELF } \\
\text { FARELF }\end{array}$ & $\begin{array}{l}\ddot{ } \\
\ddot{*} \\
\cdots\end{array}$ & $\begin{array}{l}41 \cdot 2 \\
30 \cdot 3 \\
42 \cdot 8 \\
24 \cdot 1\end{array}$ & $\begin{array}{l}36 \cdot 8 \\
32 \cdot 5 \\
48 \cdot 2 \\
26 \cdot 0\end{array}$ & $\begin{array}{l}40 \cdot 1 \\
21 \cdot 4 \\
38 \cdot 6 \\
22 \cdot 1\end{array}$ & $\begin{array}{l}45 \cdot 7 \\
28 \cdot 1 \\
36 \cdot 1 \\
24 \cdot 8\end{array}$ & $\begin{array}{l}35 \cdot 6 \\
25 \cdot 4 \\
24 \cdot 0 \\
24 \cdot 7\end{array}$ & $\begin{array}{l}32 \cdot 9 \\
22 \cdot 5 \\
25 \cdot 1 \\
19 \cdot 6\end{array}$ & $\begin{array}{l}30 \cdot 4 \\
14 \cdot 5 \\
28 \cdot 7 \\
20 \cdot 4\end{array}$ & $\begin{array}{l}37 \cdot 5 \\
25 \cdot 0 \\
34 \cdot 8 \\
23 \cdot 1\end{array}$ & $\begin{array}{r}15 \cdot 3 \\
18 \cdot 0 \\
24 \cdot 2 \\
6.4\end{array}$ \\
\hline & & Range . . & $\cdots$ & $18 \cdot 7$ & $22 \cdot 2$ & $18 \cdot 7$ & $20 \cdot 9$ & $11 \cdot 6$ & $13 \cdot 3$ & $15 \cdot 9$ & & \\
\hline \multirow[t]{2}{*}{470} & \multirow[t]{2}{*}{ Common Cold } & $\begin{array}{l}\text { UK } \\
\text { BAOR. } \\
\text { MELF. } \\
\text { FARELF }\end{array}$ & $\begin{array}{l}\cdots \\
\ddot{*} \\
\cdots\end{array}$ & $\begin{array}{r}22 \cdot 8 \\
6 \cdot 9 \\
3 \cdot 6 \\
11 \cdot 1\end{array}$ & $\begin{array}{r}19 \cdot 9 \\
11 \cdot 9 \\
4 \cdot 3 \\
14 \cdot 2\end{array}$ & $\begin{array}{r}21 \cdot 3 \\
5 \cdot 6 \\
3 \cdot 2 \\
9 \cdot 6\end{array}$ & $\begin{array}{r}29 \cdot 8 \\
6 \cdot 9 \\
2 \cdot 2 \\
6 \cdot 1\end{array}$ & $\begin{array}{r}26 \cdot 7 \\
6 \cdot 9 \\
1 \cdot 1 \\
5 \cdot 7\end{array}$ & $\begin{array}{r}24 \cdot 9 \\
5 \cdot 2 \\
1 \cdot 6 \\
2 \cdot 4\end{array}$ & $\begin{array}{r}21 \cdot 1 \\
4 \cdot 7 \\
2 \cdot 2 \\
3 \cdot 3\end{array}$ & $\begin{array}{r}23 \cdot 8 \\
6 \cdot 9 \\
2 \cdot 6 \\
7 \cdot 5\end{array}$ & $\begin{array}{r}9 \cdot 9 \\
7 \cdot 2 \\
3 \cdot 2 \\
11 \cdot 8\end{array}$ \\
\hline & & Range .. & $\cdots$ & $19 \cdot 2$ & $15 \cdot 6$ & $18 \cdot 1$ & $27 \cdot 6$ & $25 \cdot 6$ & $23 \cdot 3$ & $18 \cdot 9$ & . & \\
\hline \multirow[t]{2}{*}{$480-483$} & \multirow[t]{2}{*}{ Influenza } & $\begin{array}{l}\text { UK } \\
\text { BAOR } \\
\text { MELF } \\
\text { FARELF }\end{array}$ & $\begin{array}{l}\cdots \\
\cdots \\
\cdots\end{array}$ & $\begin{array}{r}12 \cdot 0 \\
4 \cdot 0 \\
2 \cdot 8 \\
4 \cdot 1\end{array}$ & $\begin{array}{r}23 \cdot 0 \\
6 \cdot 1 \\
2 \cdot 9 \\
1 \cdot 8\end{array}$ & $\begin{array}{r}10.6 \\
4.8 \\
1.4 \\
0.9\end{array}$ & $\begin{array}{r}24 \cdot 3 \\
15 \cdot 6 \\
1 \cdot 0 \\
0 \cdot 5\end{array}$ & $\begin{array}{r}11 \cdot 3 \\
5 \cdot 5 \\
0 \cdot 4 \\
1 \cdot 0\end{array}$ & $\begin{array}{r}8 \cdot 9 \\
13 \cdot 7 \\
0 \cdot 5 \\
1 \cdot 1\end{array}$ & $\begin{array}{l}8 \cdot 7 \\
4 \cdot 5 \\
1 \cdot 6 \\
3 \cdot 2\end{array}$ & $\begin{array}{r}14 \cdot 1 \\
7 \cdot 7 \\
1 \cdot 5 \\
1 \cdot 8\end{array}$ & $\begin{array}{r}15 \cdot 6 \\
11 \cdot 6 \\
2 \cdot 5 \\
3 \cdot 6\end{array}$ \\
\hline & & ,Range .. & $\cdots$ & $9 \cdot 2$ & $21 \cdot 2$ & $9 \cdot 7$ & $23 \cdot 8$ & $10 \cdot 9$ & $13 \cdot 2$ & $7 \cdot 1$ & & \\
\hline \multirow[t]{2}{*}{$500-502$} & \multirow[t]{2}{*}{ Bronchitis $\quad$. } & $\begin{array}{l}\text { UK } \cdots \\
\text { BAOR. } \\
\text { MELF } \\
\text { FARELF }\end{array}$ & $\begin{array}{l}\cdots \\
\cdots \\
\cdots\end{array}$ & $\begin{array}{r}7 \cdot 7 \\
4 \cdot 7 \\
5 \cdot 3 \\
11 \cdot 0\end{array}$ & $\begin{array}{l}8 \cdot 8 \\
4 \cdot 2 \\
5 \cdot 8 \\
8 \cdot 7\end{array}$ & $\begin{array}{l}8 \cdot 8 \\
3 \cdot 9 \\
6 \cdot 2 \\
8 \cdot 4\end{array}$ & $\begin{array}{l}9 \cdot 3 \\
6 \cdot 2 \\
4 \cdot 4 \\
7 \cdot 7\end{array}$ & $\begin{array}{l}8 \cdot 4 \\
4 \cdot 3 \\
3 \cdot 2 \\
7 \cdot 5\end{array}$ & $\begin{array}{l}7 \cdot 0 \\
3 \cdot 5 \\
3 \cdot 2 \\
4 \cdot 4\end{array}$ & $\begin{array}{l}7 \cdot 7 \\
3 \cdot 5 \\
4 \cdot 1 \\
6 \cdot 3\end{array}$ & $\begin{array}{l}8 \cdot 2 \\
4 \cdot 3 \\
4 \cdot 6 \\
7 \cdot 7\end{array}$ & $\begin{array}{l}2 \cdot 3 \\
2 \cdot 7 \\
3 \cdot 0 \\
6 \cdot 6\end{array}$ \\
\hline & & Range . . & . & $6 \cdot 3$ & $4 \cdot 6$ & $4 \cdot 9$ & $4 \cdot 9$ & $5 \cdot 2$ & $3 \cdot 8$ & $4 \cdot 2$ & & \\
\hline \multirow[t]{2}{*}{$490-493$} & \multirow[t]{2}{*}{ Pneumonia $\quad}$. & $\begin{array}{l}\text { UK } \\
\text { BAOR } \\
\text { MELF } \\
\text { FARELF }\end{array}$ & $\begin{array}{l}\ddot{ } \\
\ddot{*} \\
\ddot{*}\end{array}$ & $\begin{array}{l}3 \cdot 6 \\
2 \cdot 0 \\
4 \cdot 0 \\
1 \cdot 7\end{array}$ & $\begin{array}{l}3 \cdot 8 \\
1 \cdot 8 \\
3 \cdot 2 \\
2 \cdot 2\end{array}$ & $\begin{array}{l}4 \cdot 3 \\
1 \cdot 6 \\
2 \cdot 6 \\
1 \cdot 8\end{array}$ & $\begin{array}{l}4 \cdot 2 \\
3 \cdot 1 \\
1 \cdot 9 \\
2 \cdot 4\end{array}$ & $\begin{array}{l}3 \cdot 8 \\
2 \cdot 9 \\
1 \cdot 5 \\
1 \cdot 6\end{array}$ & $\begin{array}{l}3 \cdot 5 \\
3 \cdot 1 \\
2 \cdot 9 \\
2 \cdot 5\end{array}$ & $\begin{array}{l}3 \cdot 3 \\
2 \cdot 0 \\
3 \cdot 1 \\
2 \cdot 5\end{array}$ & $\begin{array}{l}3 \cdot 8 \\
2 \cdot 4 \\
2 \cdot 7 \\
2 \cdot 1\end{array}$ & $\begin{array}{l}1 \cdot 0 \\
1.5 \\
2 \cdot 5 \\
0.9\end{array}$ \\
\hline & & Range . . & $\cdots$ & $2 \cdot 3$ & $2 \cdot 0$ & $2 \cdot 7$ & $2 \cdot 3$ & $2 \cdot 3$ & $1 \cdot 0$ & $1 \cdot 3$ & & \\
\hline \multirow[t]{2}{*}{ 一 } & \multirow[t]{2}{*}{$\begin{array}{l}\text { All Respiratory } \\
\text { Diseases }\end{array}$} & $\begin{array}{l}\text { UK } \\
\text { BAOR } \cdots \\
\text { MELF } \\
\text { FARELF }\end{array}$ & $\begin{array}{l}\ddot{*} \\
\ddot{*} \\
\dot{ }\end{array}$ & $\begin{array}{l}87 \cdot 3 \\
47 \cdot 9 \\
58 \cdot 5 \\
52 \cdot 0\end{array}$ & $\begin{array}{l}92 \cdot 3 \\
56 \cdot 5 \\
64 \cdot 4 \\
52 \cdot 9\end{array}$ & $\begin{array}{l}85 \cdot 1 \\
37 \cdot 3 \\
52 \cdot 0 \\
42 \cdot 8\end{array}$ & $\begin{array}{r}113 \cdot 3 \\
59 \cdot 9 \\
45 \cdot 6 \\
41 \cdot 5\end{array}$ & $\begin{array}{l}85 \cdot 8 \\
45 \cdot 0 \\
30 \cdot 2 \\
40 \cdot 5\end{array}$ & $\begin{array}{l}77 \cdot 2 \\
48 \cdot 0 \\
33 \cdot 3 \\
30 \cdot 0\end{array}$ & $\begin{array}{l}71 \cdot 2 \\
29 \cdot 2 \\
39 \cdot 7 \\
35 \cdot 7\end{array}$ & $\begin{array}{l}87 \cdot 5 \\
46 \cdot 3 \\
46 \cdot 2 \\
42 \cdot 2\end{array}$ & $\begin{array}{l}42 \cdot 1 \\
30 \cdot 7 \\
34 \cdot 2 \\
22 \cdot 9\end{array}$ \\
\hline & & Range .. & $\cdots$ & $39 \cdot 4$ & $39 \cdot 4$ & $47 \cdot 8$ & $71 \cdot 8$ & $55 \cdot 6$ & $47 \cdot 2$ & $42 \cdot 0$ & & \\
\hline
\end{tabular}

APPENDIX TABLE D

ADMISSIONS OF BRITISH ARMY MALES IN MAIN COMMANDS, 1950-1956 RATES PER 1,000 STRENGTH, OTITIS

\begin{tabular}{|c|c|c|c|c|c|c|c|c|c|c|c|c|}
\hline Int. List & Disease & \multicolumn{2}{|c|}{ Command } & 1950 & 1951 & 1952 & 1953 & 1954 & 1955 & 1956 & Average & Range \\
\hline \multirow[t]{2}{*}{390} & \multirow[t]{2}{*}{ Otitis Externa } & $\begin{array}{l}\text { UK } \\
\text { BAOR. } \\
\text { MELF. } \\
\text { FARELF }\end{array}$ & $\begin{array}{l}\cdots \\
\cdots \\
\cdots\end{array}$ & \multicolumn{2}{|c|}{$\begin{array}{l}\text { No figures } \\
\text { available }\end{array}$} & $\begin{array}{l}1 \cdot 9 \\
1 \cdot 3 \\
7 \cdot 5 \\
9 \cdot 0\end{array}$ & $\begin{array}{l}1 \cdot 5 \\
2 \cdot 1 \\
5 \cdot 4 \\
9 \cdot 0\end{array}$ & $\begin{array}{l}1 \cdot 3 \\
1 \cdot 5 \\
2 \cdot 4 \\
8 \cdot 9\end{array}$ & $\begin{array}{l}1 \cdot 1 \\
1 \cdot 2 \\
3 \cdot 2 \\
7 \cdot 2\end{array}$ & $\begin{array}{l}1 \cdot 1 \\
1 \cdot 3 \\
3 \cdot 5 \\
6 \cdot 9\end{array}$ & $\begin{array}{l}1 \cdot 4 \\
1 \cdot 5 \\
4 \cdot 4 \\
8 \cdot 2\end{array}$ & $\begin{array}{l}0 \cdot 8 \\
0 \cdot 9 \\
5 \cdot 1 \\
2 \cdot 1\end{array}$ \\
\hline & & Range .. & . & & & $7 \cdot 7$ & $7 \cdot 5$ & $7 \cdot 6$ & $6 \cdot 1$ & $5 \cdot 8$ & & \\
\hline \multirow[t]{2}{*}{$391-392$} & \multirow[t]{2}{*}{ Otitis Media .. } & $\begin{array}{l}\text { UK } \\
\text { BAOR. } \\
\text { MELF. } \\
\text { FARELF }\end{array}$ & $\begin{array}{l}\ddot{ } \\
\ddot{*}\end{array}$ & \multicolumn{2}{|c|}{$\begin{array}{l}\text { No figures } \\
\text { available }\end{array}$} & $\begin{array}{l}4 \cdot 3 \\
3 \cdot 7 \\
6 \cdot 5 \\
5 \cdot 3\end{array}$ & $\begin{array}{l}4 \cdot 0 \\
4 \cdot 3 \\
5 \cdot 1 \\
4 \cdot 2\end{array}$ & $\begin{array}{l}3 \cdot 5 \\
2 \cdot 7 \\
2 \cdot 7 \\
9 \cdot 4\end{array}$ & $\begin{array}{l}2 \cdot 9 \\
2 \cdot 5 \\
3 \cdot 6 \\
4 \cdot 8\end{array}$ & $\begin{array}{l}2 \cdot 8 \\
2 \cdot 3 \\
3 \cdot 4 \\
3 \cdot 7\end{array}$ & $\begin{array}{l}3 \cdot 5 \\
3 \cdot 1 \\
4 \cdot 3 \\
5 \cdot 5\end{array}$ & $\begin{array}{l}1 \cdot 5 \\
2 \cdot 0 \\
3 \cdot 8 \\
5 \cdot 7\end{array}$ \\
\hline & & Range . . & $\cdots$ & & & $2 \cdot 8$ & $1 \cdot 1$ & $6 \cdot 7$ & $2 \cdot 3$ & $1 \cdot 4$ & & \\
\hline \multirow[t]{2}{*}{$390-392$} & \multirow[t]{2}{*}{$\begin{array}{l}\text { Otitis Externa } \\
\text { and Media .. }\end{array}$} & $\begin{array}{l}\text { UK } \\
\text { BAOR.. } \\
\text { MELF. } \\
\text { FARELF }\end{array}$ & $\begin{array}{l}\ddot{ } \\
\ddot{*} \\
\dot{ }\end{array}$ & $\begin{array}{r}4 \cdot 2 \\
7 \cdot 3 \\
12 \cdot 6 \\
21 \cdot 5\end{array}$ & $\begin{array}{r}4 \cdot 9 \\
5 \cdot 3 \\
13 \cdot 7 \\
19 \cdot 1\end{array}$ & $\begin{array}{r}6 \cdot 1 \\
5 \cdot 1 \\
14 \cdot 0 \\
14 \cdot 4\end{array}$ & $\begin{array}{r}5 \cdot 5 \\
6 \cdot 4 \\
10 \cdot 5 \\
13 \cdot 2\end{array}$ & $\begin{array}{r}4 \cdot 8 \\
4 \cdot 2 \\
5 \cdot 1 \\
18 \cdot 2\end{array}$ & $\begin{array}{r}3 \cdot 9 \\
3 \cdot 7 \\
6 \cdot 8 \\
12 \cdot 0\end{array}$ & $\begin{array}{r}4 \cdot 0 \\
3 \cdot 6 \\
6 \cdot 9 \\
10 \cdot 6\end{array}$ & $\begin{array}{r}4 \cdot 8 \\
5 \cdot 1 \\
9 \cdot 9 \\
15 \cdot 6\end{array}$ & $\begin{array}{r}2 \cdot 2 \\
3 \cdot 7 \\
8 \cdot 9 \\
10 \cdot 9\end{array}$ \\
\hline & & Range . . & . & $17 \cdot 3$ & $14 \cdot 2$ & $9 \cdot 3$ & $7 \cdot 7$ & $14 \cdot 0$ & $8 \cdot 3$ & $7 \cdot 0$ & & \\
\hline
\end{tabular}


APPENDIX TABLE E

ADMISSIONS OF BRITISH ARMY MALES IN MAIN COMMANDS, 1950-1956 RATES PER 1,000 STRENGTH, SKIN CONDITIONS

\begin{tabular}{|c|c|c|c|c|c|c|c|c|c|c|c|c|}
\hline Int. List & Disease & Comma & & 1950 & 1951 & 1952 & 1953 & 1954 & 1955 & 1956 & Average & Range \\
\hline \multirow[t]{2}{*}{$\begin{array}{l}690-694 \\
696-698\end{array}$} & \multirow{2}{*}{$\begin{array}{c}\text { Boils, Carbuncles } \\
\text { Cellulitis, and } \\
\text { Other Septic } \\
\text { Conditions .. }\end{array}$} & $\begin{array}{l}\text { UK } \\
\text { BAOR. } \\
\text { MELF. } \\
\text { FARELF }\end{array}$ & $\begin{array}{l}\cdots \\
\cdots \\
\cdots\end{array}$ & $\begin{array}{l}32 \cdot 0 \\
31 \cdot 7 \\
53 \cdot 4 \\
48 \cdot 6\end{array}$ & $\begin{array}{l}24 \cdot 8 \\
30 \cdot 5 \\
52 \cdot 5 \\
40 \cdot 5\end{array}$ & $\begin{array}{l}23 \cdot 4 \\
18 \cdot 0 \\
40 \cdot 8 \\
35 \cdot 4\end{array}$ & $\begin{array}{l}20 \cdot 9 \\
19 \cdot 4 \\
28 \cdot 1 \\
27 \cdot 9\end{array}$ & $\begin{array}{l}16 \cdot 7 \\
20 \cdot 1 \\
16 \cdot 5 \\
22 \cdot 0\end{array}$ & $\begin{array}{l}14 \cdot 3 \\
19 \cdot 3 \\
12 \cdot 3 \\
17 \cdot 3\end{array}$ & $\begin{array}{l}12 \cdot 1 \\
13 \cdot 5 \\
22 \cdot 0 \\
27 \cdot 2\end{array}$ & $\begin{array}{l}20 \cdot 6 \\
21 \cdot 8 \\
32 \cdot 2 \\
31 \cdot 3\end{array}$ & $\begin{array}{l}19 \cdot 9 \\
18 \cdot 3 \\
41 \cdot 1 \\
31 \cdot 3\end{array}$ \\
\hline & & Range . . & . & $21 \cdot 7$ & $27 \cdot 7$ & $22 \cdot 8$ & $8 \cdot 7$ & $5 \cdot 5$ & $7 \cdot 0$ & $15 \cdot 1$ & & \\
\hline \multirow[t]{2}{*}{695} & \multirow[t]{2}{*}{ Impetigo } & $\begin{array}{l}\text { UK } \\
\text { BAOR } \\
\text { MELF. } \\
\text { FARELF }\end{array}$ & $\begin{array}{l}\cdots \\
\cdots \\
\cdots\end{array}$ & $\begin{array}{l}2 \cdot 5 \\
4 \cdot 2 \\
3 \cdot 9 \\
8 \cdot 3\end{array}$ & $\begin{array}{l}2 \cdot 3 \\
3 \cdot 8 \\
4 \cdot 8 \\
5 \cdot 0\end{array}$ & $\begin{array}{l}2 \cdot 9 \\
4 \cdot 1 \\
3 \cdot 9 \\
3 \cdot 4\end{array}$ & $\begin{array}{l}3 \cdot 0 \\
4 \cdot 2 \\
2 \cdot 9 \\
6 \cdot 2\end{array}$ & $\begin{array}{l}3 \cdot 3 \\
4 \cdot 8 \\
2 \cdot 0 \\
6 \cdot 0\end{array}$ & $\begin{array}{l}3 \cdot 2 \\
3 \cdot 7 \\
3 \cdot 0 \\
4 \cdot 3\end{array}$ & $\begin{array}{l}1 \cdot 6 \\
1 \cdot 6 \\
1 \cdot 4 \\
4 \cdot 1\end{array}$ & $\begin{array}{l}2 \cdot 7 \\
3 \cdot 8 \\
3 \cdot 1 \\
5 \cdot 3\end{array}$ & $\begin{array}{l}1 \cdot 7 \\
3 \cdot 2 \\
3 \cdot 4 \\
4 \cdot 9\end{array}$ \\
\hline & & Range ... & $\ldots$ & $5 \cdot 8$ & $2 \cdot 7$ & $1 \cdot 2$ & $3 \cdot 3$ & $4 \cdot 0$ & $1 \cdot 3$ & $2 \cdot 7$ & & \\
\hline \multirow[t]{2}{*}{$\begin{array}{l}\text { Part of } \\
714 \cdot 0\end{array}$} & \multirow[t]{2}{*}{ Prickly Heat . } & $\begin{array}{l}\text { UK } \\
\text { BAOR. } \\
\text { MELF. } \\
\text { FARELF }\end{array}$ & $\begin{array}{l}\cdots \\
\cdots \\
\cdots\end{array}$ & $\begin{array}{l}0 \cdot 2 \\
0 \cdot 1 \\
0 \cdot 5 \\
0 \cdot 6\end{array}$ & $\begin{array}{l}0 \cdot 0 \\
0 \cdot 1 \\
0 \cdot 3 \\
0 \cdot 6\end{array}$ & $\begin{array}{l}0 \cdot 2 \\
0 \cdot 3 \\
0 \cdot 4\end{array}$ & $\begin{array}{l}0 \cdot 0 \\
0 \cdot 0 \\
0 \cdot 2 \\
0 \cdot 9\end{array}$ & $\begin{array}{l}0 \cdot 0 \\
0 \cdot 0 \\
0 \cdot 1 \\
1 \cdot 7\end{array}$ & $\begin{array}{l}0 \cdot 0 \\
0 \cdot 0 \\
0 \cdot 4 \\
1 \cdot 0\end{array}$ & $\begin{array}{l}0 \cdot 0 \\
0 \cdot 0 \\
0 \cdot 3 \\
0 \cdot 5\end{array}$ & $\begin{array}{l}0 \cdot 1 \\
0 \cdot 0 \\
0 \cdot 3 \\
0 \cdot 8\end{array}$ & $\begin{array}{l}0 \cdot 2 \\
0 \cdot 1 \\
0 \cdot 4 \\
1 \cdot 3\end{array}$ \\
\hline & & Range . . & $\ldots$ & 0.5 & 0.6 & $0 \cdot 4$ & 0.9 & $1 \cdot 7$ & $1 \cdot 0$ & 0.5 & & \\
\hline \multirow[t]{2}{*}{135} & \multirow[t]{2}{*}{ Scabies } & $\begin{array}{l}\text { UK } \\
\text { BAOR } \\
\text { MELF } \\
\text { FARELF }\end{array}$ & $\begin{array}{l}\ldots \\
\cdots \\
\ldots\end{array}$ & $\begin{array}{l}0.5 \\
0.6 \\
0.7 \\
0.4\end{array}$ & $\begin{array}{l}0 \cdot 3 \\
0 \cdot 7 \\
0 \cdot 2 \\
0 \cdot 3\end{array}$ & $\begin{array}{l}0 \cdot 3 \\
0 \cdot 3 \\
0 \cdot 2 \\
0 \cdot 2\end{array}$ & $\begin{array}{l}0.4 \\
0.4 \\
0.1 \\
0.4\end{array}$ & $\begin{array}{l}0 \cdot 2 \\
0 \cdot 4 \\
0 \cdot 0 \\
0 \cdot 1\end{array}$ & $\begin{array}{l}0 \cdot 5 \\
0 \cdot 4 \\
0 \cdot 1 \\
0 \cdot 3\end{array}$ & $\begin{array}{l}0 \cdot 4 \\
0 \cdot 3 \\
0 \cdot 3 \\
0 \cdot 1\end{array}$ & $\begin{array}{l}0 \cdot 4 \\
0 \cdot 4 \\
0 \cdot 2 \\
0 \cdot 3\end{array}$ & $\begin{array}{l}0 \cdot 3 \\
0 \cdot 4 \\
0 \cdot 7 \\
0 \cdot 3\end{array}$ \\
\hline & & Range . . & $\ldots$ & $0 \cdot 3$ & 0.5 & $0 \cdot 1$ & $0 \cdot 3$ & 0.4 & 0.4 & $0 \cdot 3$ & & \\
\hline \multirow[t]{2}{*}{131} & \multirow[t]{2}{*}{ Tinea Pedis } & $\begin{array}{l}\text { UK } \\
\text { BAOR. } \\
\text { MELF. } \\
\text { FARELF }\end{array}$ & $\begin{array}{l}\ldots \\
\ldots \\
\ldots\end{array}$ & $\begin{array}{l}0.5 \\
0.7 \\
1 \cdot 8 \\
3 \cdot 0\end{array}$ & $\begin{array}{l}0 \cdot 5 \\
0 \cdot 3 \\
1 \cdot 9 \\
4 \cdot 4\end{array}$ & $\begin{array}{l}0 \cdot 4 \\
0 \cdot 6 \\
1 \cdot 3 \\
3 \cdot 7\end{array}$ & $\begin{array}{l}0.4 \\
0.4 \\
1.6 \\
3.0\end{array}$ & $\begin{array}{l}0 \cdot 3 \\
0 \cdot 7 \\
0 \cdot 2 \\
4 \cdot 0\end{array}$ & $\begin{array}{l}0 \cdot 4 \\
1 \cdot 3 \\
1 \cdot 1 \\
5 \cdot 0\end{array}$ & $\begin{array}{l}0.6 \\
0.9 \\
1.9 \\
7 \cdot 7\end{array}$ & $\begin{array}{l}0.4 \\
0.7 \\
1.4 \\
4 \cdot 4\end{array}$ & $\begin{array}{l}0 \cdot 3 \\
1 \cdot 0 \\
1 \cdot 7 \\
4 \cdot 7\end{array}$ \\
\hline & & Range . . & $\cdots$ & $2 \cdot 5$ & $4 \cdot 1$ & $3 \cdot 3$ & $2 \cdot 6$ & $3 \cdot 8$ & $4 \cdot 6$ & $7 \cdot 1$ & & \\
\hline \multirow[t]{2}{*}{131} & \multirow[t]{2}{*}{ Tinea Elsewhere } & $\begin{array}{l}\text { UK } \\
\text { BAOR. } \\
\text { MELF. } \\
\text { FARELF }\end{array}$ & $\begin{array}{l}\ldots \\
\ldots \\
\ldots\end{array}$ & $\begin{array}{r}0.2 \\
0 \cdot 5 \\
0.6 \\
17 \cdot 9\end{array}$ & $\begin{array}{l}0 \cdot 2 \\
0 \cdot 2 \\
1 \cdot 0 \\
9 \cdot 8\end{array}$ & $\begin{array}{r}0.4 \\
0.3 \\
0.6 \\
13.6\end{array}$ & $\begin{array}{r}0.4 \\
0 \cdot 1 \\
0.2 \\
12.8\end{array}$ & $\begin{array}{l}0 \cdot 2 \\
0 \cdot 4 \\
0 \cdot 1 \\
7 \cdot 6\end{array}$ & $\begin{array}{l}0 \cdot 4 \\
1 \cdot 3 \\
0 \cdot 5 \\
5 \cdot 2\end{array}$ & $\begin{array}{r}0.4 \\
1.2 \\
0.4 \\
10.3\end{array}$ & $\begin{array}{r}0.3 \\
0.6 \\
0.5 \\
11.0\end{array}$ & $\begin{array}{r}0.2 \\
1 \cdot 2 \\
0.9 \\
12 \cdot 7\end{array}$ \\
\hline & & Range . . & $\cdots$ & $17 \cdot 7$ & $9 \cdot 6$ & $13 \cdot 3$ & $12 \cdot 7$ & $7 \cdot 5$ & $4 \cdot 8$ & $9 \cdot 9$ & & \\
\hline \multirow[t]{2}{*}{$\begin{array}{c}052 \\
\text { Rest of } \\
700-716\end{array}$} & \multirow[t]{2}{*}{$\begin{array}{c}\text { All Other Skin } \\
\text { Diseases }\end{array}$} & $\begin{array}{l}\text { UK } \\
\text { BAOR. } \\
\text { MELF. } \\
\text { FARELF }\end{array}$ & $\begin{array}{l}\cdots \\
\cdots \\
\cdots\end{array}$ & $\begin{array}{r}8 \cdot 7 \\
19 \cdot 0 \\
18 \cdot 7 \\
36 \cdot 5\end{array}$ & $\begin{array}{r}7 \cdot 5 \\
16 \cdot 5 \\
17 \cdot 6 \\
27 \cdot 0\end{array}$ & $\begin{array}{r}9 \cdot 0 \\
12 \cdot 2 \\
15 \cdot 7 \\
19 \cdot 6\end{array}$ & $\begin{array}{r}9 \cdot 2 \\
14.9 \\
11.4 \\
18.9\end{array}$ & $\begin{array}{r}9 \cdot 0 \\
14 \cdot 2 \\
7 \cdot 9 \\
17 \cdot 1\end{array}$ & $\begin{array}{r}8 \cdot 8 \\
11 \cdot 9 \\
11 \cdot 1 \\
17 \cdot 0\end{array}$ & $\begin{array}{r}7 \cdot 8 \\
11 \cdot 1 \\
14 \cdot 0 \\
12 \cdot 1\end{array}$ & $\begin{array}{r}8 \cdot 6 \\
14 \cdot 3 \\
13 \cdot 8 \\
21 \cdot 2\end{array}$ & $\begin{array}{r}1 \cdot 7 \\
7 \cdot 9 \\
10 \cdot 8 \\
24 \cdot 4\end{array}$ \\
\hline & & Range . . & $\cdots$ & $27 \cdot 8$ & $19 \cdot 5$ & $10 \cdot 6$ & $9 \cdot 7$ & $9 \cdot 2$ & $8 \cdot 2$ & $6 \cdot 2$ & & \\
\hline \multirow[t]{2}{*}{-} & \multirow[t]{2}{*}{$\begin{array}{l}\text { All Skin } \\
\text { Conditions ... }\end{array}$} & $\begin{array}{l}\text { UK } \\
\text { BAOR. } \\
\text { MELF. } \\
\text { FARELF }\end{array}$ & $\begin{array}{l}\cdots \\
\cdots \\
\cdots\end{array}$ & $\begin{array}{r}44 \cdot 5 \\
56 \cdot 8 \\
79 \cdot 5 \\
115 \cdot 3\end{array}$ & $\begin{array}{l}35 \cdot 6 \\
52 \cdot 1 \\
78 \cdot 3 \\
87 \cdot 6\end{array}$ & $\begin{array}{l}36 \cdot 6 \\
35 \cdot 5 \\
62 \cdot 8 \\
76 \cdot 3\end{array}$ & $\begin{array}{l}34 \cdot 3 \\
39 \cdot 5 \\
44 \cdot 5 \\
69 \cdot 9\end{array}$ & $\begin{array}{l}29 \cdot 7 \\
40 \cdot 6 \\
26.7 \\
58.6\end{array}$ & $\begin{array}{l}27 \cdot 7 \\
37 \cdot 8 \\
28 \cdot 5 \\
50 \cdot 1\end{array}$ & $\begin{array}{l}22 \cdot 9 \\
28 \cdot 5 \\
40 \cdot 3 \\
61 \cdot 8\end{array}$ & $\begin{array}{l}33 \cdot 0 \\
41 \cdot 5 \\
51 \cdot 5 \\
74 \cdot 2\end{array}$ & $\begin{array}{l}21 \cdot 6 \\
28 \cdot 3 \\
52 \cdot 8 \\
65 \cdot 2\end{array}$ \\
\hline & & Range & $\ldots$ & $70 \cdot 8$ & $52 \cdot 0$ & $40 \cdot 8$ & $35 \cdot 6$ & $31 \cdot 9$ & $22 \cdot 4$ & $38 \cdot 9$ & & \\
\hline
\end{tabular}


APPENDix TABLE $F$

ADMISSIONS OF BRITISH ARMY MALES IN MAIN COMMANDS, 1950-1956 RATES PER 1,000 STRENGTH, VENEREAL DISEASES

\begin{tabular}{|c|c|c|c|c|c|c|c|c|c|c|c|c|}
\hline $\begin{array}{c}\text { Int. List } \\
\text { No. }\end{array}$ & Disease & Comma & & 1950 & 1951 & 1952 & 1953 & 1954 & 1955 & 1956 & Average & Range \\
\hline \multirow[t]{2}{*}{021} & \multirow[t]{2}{*}{ Early Syphilis.. } & $\begin{array}{l}\text { UK } \\
\text { BAOR. } \\
\text { MELF } \\
\text { FARELF }\end{array}$ & $\begin{array}{l}\cdots \\
\cdots \\
\cdots\end{array}$ & $\begin{array}{l}0 \cdot 5 \\
1 \cdot 8 \\
2 \cdot 8 \\
6 \cdot 5\end{array}$ & $\begin{array}{l}0 \cdot 3 \\
0 \cdot 8 \\
1 \cdot 2 \\
3 \cdot 1\end{array}$ & $\begin{array}{l}0 \cdot 2 \\
0 \cdot 3 \\
0 \cdot 3 \\
2 \cdot 8\end{array}$ & $\begin{array}{l}0 \cdot 1 \\
0 \cdot 2 \\
0 \cdot 4 \\
1 \cdot 0\end{array}$ & $\begin{array}{l}0 \cdot 1 \\
0 \cdot 2 \\
0 \cdot 1 \\
0 \cdot 5\end{array}$ & $\begin{array}{l}0 \cdot 1 \\
0 \cdot 1 \\
0 \cdot 2 \\
1 \cdot 6\end{array}$ & $\begin{array}{l}0 \cdot 1 \\
0 \cdot 1 \\
0 \cdot 1 \\
0 \cdot 5\end{array}$ & $\begin{array}{l}0 \cdot 2 \\
0 \cdot 5 \\
0 \cdot 7 \\
2 \cdot 3\end{array}$ & $\begin{array}{l}0.4 \\
1.7 \\
2.7 \\
6.0\end{array}$ \\
\hline & & Range .. & $\cdots$ & $6 \cdot 0$ & $2 \cdot 8$ & $2 \cdot 6$ & 0.9 & 0.4 & $1 \cdot 5$ & 0.4 & & \\
\hline \multirow[t]{2}{*}{$\begin{array}{c}020 \\
022-029\end{array}$} & \multirow[t]{2}{*}{ Other Syphilis } & $\begin{array}{l}\text { UK } \\
\text { BAOR.. } \\
\text { MELF.. } \\
\text { FARELF }\end{array}$ & $\begin{array}{l}\cdots \\
\cdots \\
\cdots\end{array}$ & $\begin{array}{l}0 \cdot 1 \\
0 \cdot 2 \\
0 \cdot 6 \\
0 \cdot 2\end{array}$ & $\begin{array}{l}0 \cdot 1 \\
0 \cdot 1 \\
0 \cdot 1 \\
0 \cdot 5\end{array}$ & $\begin{array}{l}0 \cdot 2 \\
0 \cdot 2 \\
0 \cdot 1 \\
0 \cdot 1\end{array}$ & $\begin{array}{l}0 \cdot 1 \\
0 \cdot 5 \\
0 \cdot 2 \\
0 \cdot 1\end{array}$ & $\begin{array}{l}0 \cdot 0 \\
0 \cdot 0 \\
0 \cdot 0 \\
0 \cdot 1\end{array}$ & $\begin{array}{l}0 \cdot 1 \\
0 \cdot 0 \\
0 \cdot 1 \\
0 \cdot 1\end{array}$ & $\begin{array}{l}0.1 \\
0.3 \\
0.0 \\
-\end{array}$ & $\begin{array}{l}0 \cdot 1 \\
0 \cdot 2 \\
0 \cdot 2 \\
0 \cdot 2\end{array}$ & $\begin{array}{l}0.2 \\
0.5 \\
0.6 \\
0.5\end{array}$ \\
\hline & & Range . . & $\cdots$ & 0.5 & 0.4 & $0 \cdot 1$ & 0.4 & $0 \cdot 1$ & $0 \cdot 1$ & $0 \cdot 3$ & & \\
\hline \multirow[t]{2}{*}{$030-035$} & \multirow[t]{2}{*}{$\begin{array}{c}\text { Gonococcal } \\
\text { Infection }\end{array}$} & $\begin{array}{l}\text { UK } \\
\text { BAOR. } \\
\text { MELF. } \\
\text { FARELF }\end{array}$ & $\begin{array}{l}\cdots \\
\cdots \\
\cdots\end{array}$ & $\begin{array}{r}2 \cdot 5 \\
15 \cdot 3 \\
8 \cdot 7 \\
60 \cdot 4\end{array}$ & $\begin{array}{r}1 \cdot 6 \\
11 \cdot 3 \\
7 \cdot 5 \\
64 \cdot 9\end{array}$ & $\begin{array}{r}1 \cdot 4 \\
7 \cdot 2 \\
4 \cdot 1 \\
40 \cdot 5\end{array}$ & $\begin{array}{r}1 \cdot 4 \\
5 \cdot 4 \\
2 \cdot 8 \\
30 \cdot 1\end{array}$ & $\begin{array}{r}0 \cdot 5 \\
4 \cdot 2 \\
3 \cdot 9 \\
31 \cdot 7\end{array}$ & $\begin{array}{r}0 \cdot 4 \\
3 \cdot 6 \\
2 \cdot 3 \\
33 \cdot 7\end{array}$ & $\begin{array}{r}0 \cdot 3 \\
3 \cdot 4 \\
4 \cdot 0 \\
28 \cdot 9\end{array}$ & $\begin{array}{r}1 \cdot 2 \\
7 \cdot 2 \\
4 \cdot 8 \\
41 \cdot 5\end{array}$ & $\begin{array}{r}2.2 \\
11.9 \\
6.4 \\
36.0\end{array}$ \\
\hline & & Range . . & $\cdots$ & $57 \cdot 9$ & $63 \cdot 3$ & $39 \cdot 1$ & $28 \cdot 7$ & $31 \cdot 2$ & $33 \cdot 3$ & $28 \cdot 6$ & & \\
\hline \multirow[t]{2}{*}{$\begin{array}{c}\text { Part of } \\
039\end{array}$} & \multirow[t]{2}{*}{$\begin{array}{c}\text { Non-gonococcal } \\
\text { Urethritis }\end{array}$} & $\begin{array}{l}\text { UK } \\
\text { BAOR } \\
\text { MELF } \\
\text { FARELF }\end{array}$ & $\begin{array}{l}\cdots \\
\cdots \\
\cdots\end{array}$ & $\begin{array}{r}2 \cdot 0 \\
5 \cdot 7 \\
6 \cdot 7 \\
35 \cdot 2\end{array}$ & $\begin{array}{r}2 \cdot 3 \\
3 \cdot 4 \\
6 \cdot 6 \\
35 \cdot 9\end{array}$ & $\begin{array}{r}2 \cdot 4 \\
62 \\
5 \cdot 1 \\
29 \cdot 2\end{array}$ & $\begin{array}{r}2 \cdot 2 \\
5 \cdot 3 \\
5 \cdot 1 \\
29 \cdot 0\end{array}$ & $\begin{array}{r}1 \cdot 3 \\
3 \cdot 3 \\
7 \cdot 4 \\
29 \cdot 1\end{array}$ & $\begin{array}{r}1 \cdot 3 \\
3 \cdot 5 \\
5 \cdot 4 \\
28 \cdot 1\end{array}$ & $\begin{array}{r}1 \cdot 2 \\
3 \cdot 2 \\
3 \cdot 0 \\
32 \cdot 5\end{array}$ & $\begin{array}{r}1 \cdot 8 \\
4 \cdot 4 \\
5 \cdot 6 \\
31 \cdot 3\end{array}$ & $\begin{array}{l}1 \cdot 2 \\
3 \cdot 0 \\
4 \cdot 4 \\
7 \cdot 8\end{array}$ \\
\hline & & Range . . & $\ldots$ & $33 \cdot 2$ & $33 \cdot 6$ & $26 \cdot 8$ & $26 \cdot 8$ & $27 \cdot 8$ & $26 \cdot 8$ & $31 \cdot 3$ & & \\
\hline \multirow[t]{2}{*}{036} & \multirow[t]{2}{*}{ Chancroid } & $\begin{array}{l}\text { UK } \\
\text { BAOR . . } \\
\text { MELF } \\
\text { FARELF }\end{array}$ & $\begin{array}{l}\cdots \\
\cdots \\
\cdots\end{array}$ & $\begin{array}{r}0 \cdot 6 \\
1 \cdot 5 \\
5 \cdot 7 \\
23 \cdot 7\end{array}$ & $\begin{array}{r}0 \cdot 5 \\
0 \cdot 3 \\
3 \cdot 0 \\
25 \cdot 0\end{array}$ & $\begin{array}{l}0 \cdot 3 \\
0 \cdot 4 \\
0 \cdot 9 \\
6 \cdot 9\end{array}$ & $\begin{array}{l}0 \cdot 2 \\
0 \cdot 3 \\
0 \cdot 8 \\
5 \cdot 8\end{array}$ & $\begin{array}{l}0 \cdot 1 \\
0 \cdot 1 \\
0 \cdot 9 \\
6 \cdot 1\end{array}$ & $\begin{array}{l}0 \cdot 1 \\
0 \cdot 0 \\
0 \cdot 7 \\
3 \cdot 2\end{array}$ & $\begin{array}{l}0 \cdot 1 \\
0 \cdot 0 \\
0 \cdot 2 \\
5 \cdot 4\end{array}$ & $\begin{array}{r}0.3 \\
0.4 \\
1 \cdot 7 \\
10 \cdot 9\end{array}$ & $\begin{array}{r}0 \cdot 5 \\
1 \cdot 5 \\
5 \cdot 5 \\
21 \cdot 8\end{array}$ \\
\hline & & Range .. & $\cdots$ & $23 \cdot 1$ & $24 \cdot 7$ & $6 \cdot 6$ & $5 \cdot 6$ & $6 \cdot 0$ & $3 \cdot 2$ & $5 \cdot 4$ & & \\
\hline \multirow[t]{2}{*}{$020-039$} & \multirow[t]{2}{*}{$\begin{array}{c}\text { All Venereal } \\
\text { Diseases }\end{array}$} & $\begin{array}{l}\text { UK } \\
\text { BAOR. } \\
\text { MELF } \\
\text { FARELF }\end{array}$ & $\begin{array}{l}\cdots \\
\cdots \\
\cdots\end{array}$ & $\begin{array}{r}7 \cdot 3 \\
26 \cdot 9 \\
30 \cdot 9 \\
141 \cdot 2\end{array}$ & $\begin{array}{r}6 \cdot 1 \\
17 \cdot 3 \\
21 \cdot 1 \\
144 \cdot 3\end{array}$ & $\begin{array}{r}5 \cdot 5 \\
15 \cdot 3 \\
13 \cdot 4 \\
97 \cdot 6\end{array}$ & $\begin{array}{r}5 \cdot 4 \\
12 \cdot 8 \\
11 \cdot 7 \\
73 \cdot 0\end{array}$ & $\begin{array}{r}2.6 \\
7 \cdot 8 \\
15 \cdot 6 \\
73 \cdot 9\end{array}$ & $\begin{array}{r}2 \cdot 5 \\
8 \cdot 3 \\
11 \cdot 3 \\
73 \cdot 2\end{array}$ & $\begin{array}{r}2 \cdot 3 \\
8 \cdot 3 \\
8 \cdot 6 \\
79 \cdot 2\end{array}$ & $\begin{array}{r}4 \cdot 5 \\
13 \cdot 8 \\
16 \cdot 1 \\
97 \cdot 5\end{array}$ & $\begin{array}{r}5 \cdot 0 \\
19 \cdot 1 \\
22 \cdot 3 \\
71 \cdot 3\end{array}$ \\
\hline & & Range .. & $\ldots$ & $133 \cdot 9$ & $138 \cdot 2$ & $92 \cdot 1$ & $67 \cdot 6$ & $71 \cdot 3$ & $70 \cdot 7$ & $76 \cdot 9$ & & \\
\hline
\end{tabular}


APPENDIX TABLE $G$

ADMISSIONS OF BRITISH ARMY MALES IN MAIN COMMANDS, 1950-1956 RATES PER 1,000 STRENGTH, INTESTINAL DISEASES

\begin{tabular}{|c|c|c|c|c|c|c|c|c|c|c|c|c|}
\hline $\begin{array}{l}\text { Int. List } \\
\text { No. }\end{array}$ & Disease & Comma & & 1950 & 1951 & 1952 & 1953 & 1954 & 1955 & 1956 & Average & Range \\
\hline \multirow[t]{2}{*}{$\begin{array}{l}\text { Part of } \\
040\end{array}$} & \multirow[t]{2}{*}{ Typhoid } & $\begin{array}{l}\text { UK } \\
\text { BAOR } \\
\text { MELF } \\
\text { FARELF }\end{array}$ & $\begin{array}{l}\cdots \\
\cdots \\
\cdots\end{array}$ & $\begin{array}{l}0.0 \\
1.0 \\
0.2\end{array}$ & $\begin{array}{l}- \\
\overline{0} \cdot 1 \\
0 \cdot 1\end{array}$ & $\begin{array}{l}- \\
0.0 \\
0 \cdot 2 \\
0.0\end{array}$ & $\begin{array}{l}0.0 \\
\overline{0.2} \\
0 \cdot 2\end{array}$ & $\begin{array}{l}- \\
\overline{0.1} \\
0 \cdot 2\end{array}$ & $\begin{array}{l}\overline{-} \\
\overline{0} \cdot 2 \\
0 \cdot 1\end{array}$ & $\begin{array}{l}0 \cdot 0 \\
- \\
-\end{array}$ & $\begin{array}{l}0 \cdot 0 \\
0 \cdot 0 \\
0 \cdot 3 \\
0 \cdot 1\end{array}$ & $\begin{array}{l}0.0 \\
0.0 \\
1.0 \\
0.2\end{array}$ \\
\hline & & Range .. & $\ldots$ & $1 \cdot 0$ & $0 \cdot 1$ & $0 \cdot 2$ & $0 \cdot 2$ & $0 \cdot 2$ & $0 \cdot 2$ & 0.0 & & \\
\hline \multirow[t]{2}{*}{041} & \multirow[t]{2}{*}{ Paratyphoid } & $\begin{array}{l}\text { UK } \\
\text { BAOR } \\
\text { MELF. } \\
\text { FARELF }\end{array}$ & $\begin{array}{l}\cdots \\
\cdots \\
\cdots\end{array}$ & $\begin{array}{l}\overline{-} \\
\overline{0.7} \\
0.1\end{array}$ & $\begin{array}{l}0.0 \\
0.2 \\
0.1\end{array}$ & $\begin{array}{l}-\overline{3} \\
3 \cdot 4 \\
0 \cdot 0\end{array}$ & $\begin{array}{l}- \\
\overline{3 \cdot 6} \\
0.0\end{array}$ & $\begin{array}{l}0.0 \\
\overline{3.9} \\
0.1\end{array}$ & $\begin{array}{l}0.0 \\
1 \cdot 0 \\
-\end{array}$ & $\begin{array}{l}0 \cdot 0 \\
\overline{0.1} \\
0 \cdot 0\end{array}$ & $\begin{array}{l}0.0 \\
\overline{1.8} \\
0.0\end{array}$ & $\begin{array}{l}0.0 \\
3 \cdot 8 \\
0 \cdot 1\end{array}$ \\
\hline & & Range . . & $\cdots$ & 0.7 & $0 \cdot 2$ & $3 \cdot 4$ & $3 \cdot 6$ & $3 \cdot 9$ & $1 \cdot 0$ & $0 \cdot 1$ & & \\
\hline \multirow[t]{2}{*}{$\begin{array}{l}040 \\
041\end{array}$} & \multirow[t]{2}{*}{$\begin{array}{l}\text { Total } \\
\text { Enteric Fever }\end{array}$} & $\begin{array}{l}\text { UK } \\
\text { BAOR. } \\
\text { MELF. } \\
\text { FARELF }\end{array}$ & $\begin{array}{l}\cdots \\
\cdots \\
\cdots\end{array}$ & $\begin{array}{l}0.0 \\
\overline{1.9} \\
0.3\end{array}$ & $\begin{array}{l}0.0 \\
\overline{0.4} \\
0.2\end{array}$ & $\begin{array}{l}-\overline{0 \cdot 0} \\
4 \cdot 4 \\
0 \cdot 1\end{array}$ & $\begin{array}{l}0.0 \\
\overline{3} \cdot 8 \\
0 \cdot 3\end{array}$ & $\begin{array}{l}0.0 \\
\overline{4 \cdot 1} \\
0 \cdot 2\end{array}$ & $\begin{array}{l}0 \cdot 0 \\
0 \cdot 0 \\
1 \cdot 2 \\
0 \cdot 1\end{array}$ & $\begin{array}{l}0.0 \\
\overline{0.2} \\
0.1\end{array}$ & $\begin{array}{l}0 \cdot 0 \\
0 \cdot 0 \\
2 \cdot 3 \\
0 \cdot 2\end{array}$ & $\begin{array}{l}0 \cdot 0 \\
0 \cdot 0 \\
4 \cdot 2 \\
0 \cdot 2\end{array}$ \\
\hline & & Range . . & $\cdots$ & $1 \cdot 9$ & $0 \cdot 4$ & $4 \cdot 4$ & $3 \cdot 8$ & $4 \cdot 1$ & $1 \cdot 2$ & 0.2 & & \\
\hline \multirow[t]{2}{*}{$\begin{array}{l}046 \cdot 0 \\
046 \cdot 1\end{array}$} & \multirow[t]{2}{*}{ Amocbiasis $\quad}$. & $\begin{array}{l}\text { UK } \\
\text { BAOR . } \\
\text { MELF } \\
\text { FARELF }\end{array}$ & $\begin{array}{l}\cdots \\
\cdots \\
\cdots\end{array}$ & $\begin{array}{l}0 \cdot 2 \\
0 \cdot 1 \\
0 \cdot 5 \\
3 \cdot 9\end{array}$ & $\begin{array}{l}0 \cdot 2 \\
0 \cdot 1 \\
0 \cdot 3 \\
3 \cdot 8\end{array}$ & $\begin{array}{l}0 \cdot 2 \\
0 \cdot 1 \\
0 \cdot 4 \\
3 \cdot 3\end{array}$ & $\begin{array}{l}0 \cdot 2 \\
0 \cdot 0 \\
0 \cdot 2 \\
3 \cdot 1\end{array}$ & $\begin{array}{l}0 \cdot 1 \\
0 \cdot 0 \\
0 \cdot 2 \\
2 \cdot 3\end{array}$ & $\begin{array}{l}0 \cdot 0 \\
0 \cdot 0 \\
0 \cdot 1 \\
1 \cdot 6\end{array}$ & $\begin{array}{l}0 \cdot 1 \\
0 \cdot 1 \\
0 \cdot 1 \\
1 \cdot 3\end{array}$ & $\begin{array}{l}0 \cdot 1 \\
0 \cdot 1 \\
0 \cdot 3 \\
2 \cdot 8\end{array}$ & $\begin{array}{l}0 \cdot 2 \\
0 \cdot 1 \\
0 \cdot 4 \\
2 \cdot 6\end{array}$ \\
\hline & & Range . . & $\cdots$ & $3 \cdot 8$ & $3 \cdot 7$ & $3 \cdot 2$ & $3 \cdot 1$ & $2 \cdot 3$ & $1 \cdot 6$ & $1 \cdot 2$ & & \\
\hline \multirow[t]{2}{*}{$\begin{array}{c}045 \\
047-048\end{array}$} & \multirow[t]{2}{*}{$\begin{array}{l}\text { Dysentery (other } \\
\text { than Amoebic) }\end{array}$} & $\begin{array}{l}\text { UK } \\
\text { BAOR. } \\
\text { MELF } \\
\text { FARELF }\end{array}$ & $\begin{array}{l}\cdots \\
\cdots \\
\cdots\end{array}$ & $\begin{array}{r}0 \cdot 2 \\
0 \cdot 2 \\
11 \cdot 1 \\
8 \cdot 6\end{array}$ & $\begin{array}{r}0 \cdot 5 \\
0 \cdot 3 \\
16 \cdot 7 \\
7 \cdot 2\end{array}$ & $\begin{array}{r}0 \cdot 5 \\
0 \cdot 3 \\
22 \cdot 5 \\
8 \cdot 1\end{array}$ & $\begin{array}{r}0 \cdot 2 \\
0 \cdot 0 \\
27 \cdot 1 \\
7 \cdot 2\end{array}$ & $\begin{array}{r}0 \cdot 2 \\
0 \cdot 0 \\
22 \cdot 6 \\
5 \cdot 9\end{array}$ & $\begin{array}{r}0 \cdot 2 \\
0 \cdot 0 \\
23 \cdot 8 \\
5 \cdot 4\end{array}$ & $\begin{array}{r}0.3 \\
0.0 \\
18 \cdot 5 \\
2.8\end{array}$ & $\begin{array}{r}0 \cdot 3 \\
0 \cdot 1 \\
20 \cdot 3 \\
6 \cdot 5\end{array}$ & $\begin{array}{r}0 \cdot 3 \\
0 \cdot 3 \\
16 \cdot 0 \\
5 \cdot 8\end{array}$ \\
\hline & & Range .. & $\cdots$ & $10 \cdot 9$ & $16 \cdot 4$ & $22 \cdot 2$ & $27 \cdot 1$ & $22 \cdot 6$ & $23 \cdot 8$ & $18 \cdot 5$ & & \\
\hline \multirow[t]{2}{*}{\begin{tabular}{l|}
$785 \cdot 6$ \\
$571-572$ \\
042,049
\end{tabular}} & \multirow{2}{*}{$\begin{array}{l}\text { Diarrhoea, } \\
\text { Enteritis, and } \\
\text { Food Poison- } \\
\text { ing .. }\end{array}$} & $\begin{array}{l}\text { UK } \\
\text { BAOR. . } \\
\text { MELF. } \\
\text { FARELF }\end{array}$ & $\begin{array}{l}\cdots \\
\cdots \\
\cdots \\
\cdots\end{array}$ & $\begin{array}{r}6 \cdot 9 \\
6 \cdot 4 \\
40 \cdot 9 \\
27 \cdot 1 \\
\end{array}$ & $\begin{array}{r}5 \cdot 9 \\
3 \cdot 7 \\
40 \cdot 0 \\
20 \cdot 2 \\
\end{array}$ & $\begin{array}{r}5 \cdot 6 \\
4 \cdot 7 \\
41 \cdot 8 \\
18 \cdot 4 \\
\end{array}$ & $\begin{array}{r}5 \cdot 9 \\
3 \cdot 6 \\
43 \cdot 6 \\
22 \cdot 6 \\
\end{array}$ & $\begin{array}{r}4 \cdot 3 \\
3 \cdot 7 \\
27 \cdot 9 \\
24 \cdot 3 \\
\end{array}$ & $\begin{array}{r}6 \cdot 2 \\
6 \cdot 4 \\
30 \cdot 3 \\
23 \cdot 1 \\
\end{array}$ & $\begin{array}{r}6 \cdot 2 \\
3 \cdot 7 \\
44 \cdot 5 \\
25 \cdot 5 \\
\end{array}$ & $\begin{array}{r}5 \cdot 9 \\
4 \cdot 6 \\
38 \cdot 4 \\
23 \cdot 0 \\
\end{array}$ & 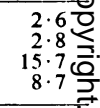 \\
\hline & & Range .. & . & $34 \cdot 5$ & $36 \cdot 3$ & $37 \cdot 1$ & $40 \cdot 0$ & $24 \cdot 2$ & $24 \cdot 1$ & $40 \cdot 8$ & & \\
\hline \multirow[t]{2}{*}{092} & \multirow[t]{2}{*}{$\begin{array}{l}\text { Infective } \\
\text { Hepatitis }\end{array}$} & $\begin{array}{l}\text { UK } \\
\text { BAOR . } \\
\text { MELF. } \\
\text { FARELF }\end{array}$ & $\begin{array}{l}\cdots \\
\cdots \\
\cdots \\
\cdots\end{array}$ & $\begin{array}{r}1 \cdot 6 \\
4 \cdot 1 \\
4 \cdot 0 \\
14 \cdot 4 \\
\end{array}$ & $\begin{array}{r}1 \cdot 1 \\
2 \cdot 0 \\
6 \cdot 7 \\
13 \cdot 2 \\
\end{array}$ & $\begin{array}{l}0 \cdot 9 \\
0 \cdot 7 \\
5 \cdot 0 \\
6 \cdot 5\end{array}$ & $\begin{array}{l}0 \cdot 7 \\
1 \cdot 0 \\
6 \cdot 8 \\
3 \cdot 8\end{array}$ & $\begin{array}{l}0 \cdot 7 \\
0 \cdot 7 \\
4 \cdot 0 \\
4 \cdot 4\end{array}$ & $\begin{array}{l}0 \cdot 4 \\
0 \cdot 7 \\
5 \cdot 0 \\
3 \cdot 3\end{array}$ & $\begin{array}{l}0 \cdot 8 \\
0 \cdot 4 \\
4 \cdot 3 \\
6 \cdot 4\end{array}$ & $\begin{array}{l}0 \cdot 9 \\
1 \cdot 4 \\
5 \cdot 0 \\
7 \cdot 4\end{array}$ & $\begin{array}{r}1 \cdot 2 \\
3 \cdot 7 \\
2 \cdot 8 \\
11 \cdot 1\end{array}$ \\
\hline & & Range .. & . & $12 \cdot 8$ & $12 \cdot 1$ & $5 \cdot 8$ & $6 \cdot 1$ & $3 \cdot 7$ & $4 \cdot 6$ & $6 \cdot 0$ & & \\
\hline \multirow[t]{2}{*}{-} & \multirow[t]{2}{*}{$\begin{array}{l}\text { All Intestinal } \\
\text { Diseases }\end{array}$} & $\begin{array}{l}\text { UK } \\
\text { BAOR. } \\
\text { MELF } \\
\text { FARELF }\end{array}$ & $\begin{array}{l}\cdots \\
\cdots \\
\cdots\end{array}$ & $\begin{array}{r}8 \cdot 9 \\
10 \cdot 8 \\
58 \cdot 4 \\
54 \cdot 3 \\
\end{array}$ & $\begin{array}{r}7 \cdot 8 \\
6 \cdot 1 \\
64 \cdot 1 \\
44 \cdot 6\end{array}$ & $\begin{array}{r}7 \cdot 2 \\
5 \cdot 8 \\
74 \cdot 1 \\
36 \cdot 4\end{array}$ & $\begin{array}{r}7 \cdot 0 \\
4 \cdot 6 \\
81 \cdot 5 \\
37 \cdot 0\end{array}$ & $\begin{array}{r}5 \cdot 3 \\
4 \cdot 4 \\
58 \cdot 8 \\
37 \cdot 1\end{array}$ & $\begin{array}{r}6 \cdot 8 \\
7 \cdot 1 \\
60 \cdot 4 \\
33 \cdot 5\end{array}$ & $\begin{array}{r}7 \cdot 4 \\
4 \cdot 0 \\
67 \cdot 7 \\
36 \cdot 1\end{array}$ & $\begin{array}{r}7 \cdot 2 \\
6 \cdot 1 \\
66 \cdot 4 \\
39 \cdot 9\end{array}$ & $\begin{array}{r}3 \cdot 6 \\
6 \cdot 8 \\
23 \cdot 1 \\
20 \cdot 8\end{array}$ \\
\hline & & Range . . & $\ldots$ & $49 \cdot 5$ & $58 \cdot 0$ & $68 \cdot 3$ & $76 \cdot 9$ & $54 \cdot 4$ & $53 \cdot 6$ & $63 \cdot 7$ & & \\
\hline
\end{tabular}


APpendix TABLE $H$

ADMISSIONS OF BRITISH ARMY MALES IN MAIN COMMANDS, 1950-1956

RATES PER 1,000 STRENGTH, PYREXIA OF UNKNOWN ORIGIN AND MALARIA

\begin{tabular}{|c|c|c|c|c|c|c|c|c|c|c|c|}
\hline $\begin{array}{l}\text { Int. List } \\
\text { No. }\end{array}$ & Disease & Command & 1950 & 1951 & 1952 & 1953 & 1954 & 1955 & 1956 & Average & Range \\
\hline \multirow[t]{3}{*}{$788 \cdot 8$} & \multirow{3}{*}{$\begin{array}{l}\text { Pyrexia of } \\
\text { Unknown } \\
\text { Origin }\end{array}$} & $\begin{array}{ll}\text { UK } & . \\
\text { BAOR } & \because \\
\text { MELLF } & \because \\
\text { FARELF } & \because\end{array}$ & $\begin{array}{r}1 \cdot 7 \\
0 \cdot 9 \\
24 \cdot 8 \\
23 \cdot 2\end{array}$ & $\begin{array}{r}1 \cdot 7 \\
1.7 \\
22 \cdot 6 \\
12.4\end{array}$ & $\begin{array}{r}1 \cdot 8 \\
1.9 \\
22 \cdot 0 \\
15 \cdot 3\end{array}$ & $\begin{array}{r}2 \cdot 6 \\
2 \cdot 0 \\
18 \cdot 6 \\
20 \cdot 5\end{array}$ & $\begin{array}{r}2 \cdot 3 \\
0 \cdot 6 \\
21 \cdot 1 \\
26 \cdot 5\end{array}$ & $\begin{array}{r}1.8 \\
0.8 \\
21 \cdot 6 \\
19 \cdot 5\end{array}$ & $\begin{array}{r}1.5 \\
0.4 \\
17.9 \\
25.1\end{array}$ & $\begin{array}{r}1 \cdot 9 \\
1 \cdot 2 \\
21 \cdot 2 \\
20 \cdot 4\end{array}$ & $\begin{array}{r}1.1 \\
1.6 \\
6.9 \\
14.1\end{array}$ \\
\hline & & Range. & $23 \cdot 9$ & 20.9 & $20 \cdot 2$ & $18 \cdot 5$ & 25.9 & $20 \cdot 8$ & $24 \cdot 7$ & & \\
\hline & & WEST AFRICA & $23 \cdot 6$ & $21 \cdot 0$ & $38 \cdot 5$ & $23 \cdot 9$ & $26 \cdot 2$ & $38 \cdot 5$ & $34 \cdot 7$ & $29 \cdot 5$ & $17 \cdot 5$ \\
\hline \multirow[t]{3}{*}{110} & \multirow{3}{*}{$\begin{array}{c}\text { Benign Tertian } \\
\text { Malaria }\end{array}$} & $\begin{array}{l}\text { UK } . . \\
\text { BAOR.: } \\
\text { MELF.: } \\
\text { FARELF }\end{array}$ & $\begin{array}{l}0.6 \\
0.2 \\
4.4 \\
8.9\end{array}$ & $\begin{array}{l}0.7 \\
0.3 \\
1.9 \\
8.8\end{array}$ & $\begin{array}{l}2 \cdot 3 \\
0 \cdot 8 \\
1.2 \\
6 \cdot 8\end{array}$ & $\begin{array}{l}2 \cdot 3 \\
0 \cdot 7 \\
2 \cdot 1 \\
4 \cdot 8\end{array}$ & $\begin{array}{l}1 \cdot 3 \\
0 \cdot 3 \\
8 \cdot 1 \\
5 \cdot 3\end{array}$ & $\begin{array}{l}0.5 \\
0.1 \\
3.5 \\
2.9\end{array}$ & $\begin{array}{l}0.2 \\
0.1 \\
0 \cdot 3 \\
1.6\end{array}$ & $\begin{array}{l}1 \cdot 1 \\
0 \cdot 4 \\
3 \cdot 1 \\
5 \cdot 6\end{array}$ & $\begin{array}{l}2.1 \\
0.7 \\
7.8 \\
7.3\end{array}$ \\
\hline & & Range.. & $8 \cdot 7$ & $8 \cdot 5$ & $6 \cdot 0$ & $4 \cdot 1$ & $7 \cdot 8$ & $3 \cdot 4$ & 1.5 & & \\
\hline & & WEST AFRICA & - & - & $5 \cdot 4$ & $4 \cdot 2$ & $2 \cdot 1$ & - & - & 1.7 & $5 \cdot 4$ \\
\hline \multirow[t]{3}{*}{112} & \multirow{3}{*}{$\begin{array}{c}\text { Malignant } \\
\text { Tertian } \\
\text { Malaria }\end{array}$} & $\begin{array}{l}\text { UK } . . \\
\text { BAOR.: } \\
\text { MELF.: } \\
\text { FARELF }\end{array}$ & $\begin{array}{l}0 \cdot 0 \\
\frac{0 \cdot 5}{5 \cdot 5} \\
2 \cdot 5\end{array}$ & $\begin{array}{l}\frac{0.0}{2.4} \\
6.2\end{array}$ & $\begin{array}{l}0.1 \\
\frac{0 \cdot 4}{3 \cdot 9} \\
3.9\end{array}$ & $\begin{array}{l}\frac{0 \cdot 0}{4} \\
\frac{7}{4 \cdot 3}\end{array}$ & $\begin{array}{l}0 \cdot 0 \\
0 \cdot 3 \\
3 \cdot 3\end{array}$ & $\begin{array}{l}0.0 \\
0.0 \\
0.0 \\
1.8\end{array}$ & $\begin{array}{l}0.0 \\
\overline{1} \cdot 4\end{array}$ & $\begin{array}{l}0 \cdot 0 \\
0 \cdot 0 \\
1 \cdot 2 \\
3 \cdot 3\end{array}$ & $\begin{array}{l}0.1 \\
0.0 \\
5.5 \\
4.8\end{array}$ \\
\hline & & Range .. & 5.5 & $6 \cdot 2$ & 3.9 & $4 \cdot 3$ & $3 \cdot 3$ & 1.8 & 1.4 & & \\
\hline & & WEST AFRICA & 65.9 & $50 \cdot 5$ & $19 \cdot 3$ & $23 \cdot 1$ & $29 \cdot 4$ & $31 \cdot 6$ & $15 \cdot 2$ & $33 \cdot 6$ & $50 \cdot 7$ \\
\hline \multirow[t]{3}{*}{$110-117$} & \multirow[t]{3}{*}{ Total Malaria } & $\begin{array}{l}\text { UK } . . \\
\text { BAOR.: } \\
\text { MELF } \\
\text { FARELF }\end{array}$ & $\begin{array}{r}0.9 \\
0 \cdot 2 \\
11 \cdot 4 \\
12 \cdot 7\end{array}$ & $\begin{array}{r}0.9 \\
0.4 \\
4.9 \\
15.2\end{array}$ & $\begin{array}{r}2 \cdot 7 \\
0 \cdot 8 \\
2 \cdot 0 \\
11 \cdot 1\end{array}$ & $\begin{array}{r}2 \cdot 5 \\
0.9 \\
3 \cdot 0 \\
10 \cdot 0\end{array}$ & $\begin{array}{l}1.4 \\
0.3 \\
8.5 \\
8.9\end{array}$ & $\begin{array}{l}0.7 \\
0.2 \\
3.8 \\
4.7 \\
\end{array}$ & $\begin{array}{l}0 \cdot 3 \\
0 \cdot 2 \\
0 \cdot 4 \\
3 \cdot 5\end{array}$ & $\begin{array}{l}1 \cdot 3 \\
0.4 \\
4 \cdot 9 \\
9 \cdot 4\end{array}$ & $\begin{array}{r}2.4 \\
0.7 \\
11.0 \\
11.7\end{array}$ \\
\hline & & Range .. & $12 \cdot 5$ & $14 \cdot 8$ & $10 \cdot 3$ & $9 \cdot 1$ & $8 \cdot 6$ & $4 \cdot 5$ & $3 \cdot 3$ & & \\
\hline & & WEST AFRICA & $84 \cdot 4$ & $100 \cdot 4$ & $61 \cdot 6$ & $38 \cdot 4$ & $36 \cdot 4$ & $44 \cdot 7$ & $20 \cdot 2$ & $55 \cdot 2$ & $80 \cdot 2$ \\
\hline
\end{tabular}

APPENDIX TABLE I

ADMISSIONS BRITISH ARMY OF MALES IN MAIN COMMANDS, 1950-1956

RATES PER 1,000 STRENGTH, APPENDICITIS AND PEPTIC ULCERATION

\begin{tabular}{|c|c|c|c|c|c|c|c|c|c|c|c|c|}
\hline $\begin{array}{l}\text { Int. List } \\
\text { No. }\end{array}$ & Disease & Comma & & 1950 & 1951 & 1952 & 1953 & 1954 & 1955 & 1956 & Average & Range \\
\hline \multirow[t]{2}{*}{$550-553$} & \multirow[t]{2}{*}{ Appendicitis .. } & $\begin{array}{l}\text { UK } \\
\text { BAOR. } \\
\text { MELF } \\
\text { FARELF }\end{array}$ & $\begin{array}{l}. . \\
\because \\
\because .\end{array}$ & $\begin{array}{l}7.9 \\
6.6 \\
5.5 \\
7.6\end{array}$ & $\begin{array}{l}7 \cdot 7 \\
6.2 \\
7.8 \\
8.7\end{array}$ & $\begin{array}{l}9 \cdot 2 \\
6 \cdot 1 \\
7 \cdot 3 \\
7 \cdot 6\end{array}$ & $\begin{array}{l}8.5 \\
7.4 \\
7.8 \\
7.0\end{array}$ & $\begin{array}{l}8 \cdot 3 \\
6.4 \\
6.9 \\
6 \cdot 7\end{array}$ & $\begin{array}{l}7 \cdot 6 \\
6.5 \\
7 \cdot 2 \\
6.0\end{array}$ & $\begin{array}{l}7 \cdot 8 \\
5 \cdot 5 \\
6 \cdot 8 \\
6 \cdot 8\end{array}$ & $\begin{array}{l}8.1 \\
6.4 \\
7 \cdot 0 \\
7.2\end{array}$ & $\begin{array}{l}1.6 \\
1.9 \\
2.3 \\
2.7\end{array}$ \\
\hline & & Range ... & .. & $2 \cdot 4$ & $2 \cdot 5$ & $3 \cdot 1$ & 1.5 & 1.9 & 1.6 & $2 \cdot 3$ & & \\
\hline \multirow[t]{2}{*}{$\begin{array}{c}\text { Part of } \\
540\end{array}$} & \multirow[t]{2}{*}{$\begin{array}{l}\text { Peptic Ulcer- } \\
\text { Stomach }\end{array}$} & $\begin{array}{l}\text { UK } . . \\
\text { BAOR.: } \\
\text { MELF } \\
\text { FARELF }\end{array}$ & $\begin{array}{l}. . \\
\ddot{.} \\
.\end{array}$ & $\begin{array}{l}1.7 \\
2.0 \\
0.7 \\
1.1\end{array}$ & $\begin{array}{l}1 \cdot 6 \\
1 \cdot 0 \\
1 \cdot 1 \\
1 \cdot 1\end{array}$ & $\begin{array}{l}2.0 \\
1.1 \\
0.8 \\
1.0\end{array}$ & $\begin{array}{l}1.8 \\
1.6 \\
0.7 \\
0.8\end{array}$ & $\begin{array}{l}1.1 \\
1.4 \\
0.5 \\
0.3\end{array}$ & $\begin{array}{l}0.8 \\
0.9 \\
0.6 \\
0.5\end{array}$ & $\begin{array}{l}0.6 \\
0.7 \\
1.0 \\
0.5\end{array}$ & $\begin{array}{l}1.4 \\
1.2 \\
0.8 \\
0.8 \\
\end{array}$ & $\begin{array}{l}1.4 \\
1.3 \\
0.6 \\
0.8 \\
\end{array}$ \\
\hline & & Range .. &.. & $1 \cdot 3$ & 0.6 & $1 \cdot 2$ & $1 \cdot 1$ & $1 \cdot 1$ & 0.4 & 0.5 & & \\
\hline \multirow[t]{2}{*}{541} & \multirow[t]{2}{*}{$\begin{array}{c}\text { Peptic Ulcer- } \\
\text { Duodenum... }\end{array}$} & $\begin{array}{l}\text { UK } . . \\
\text { BAOR:. } \\
\text { MELF.: } \\
\text { FARELF }\end{array}$ & $\begin{array}{l}. \\
\because \\
.\end{array}$ & $\begin{array}{l}2.5 \\
1.6 \\
1.3 \\
1.4 \\
\end{array}$ & $\begin{array}{ll}2.4 \\
1.4 \\
1.1 \\
1.1 \\
\end{array}$ & $\begin{array}{l}2.9 \\
1.7 \\
1.2 \\
2.6 \\
\end{array}$ & $\begin{array}{l}2 \cdot 7 \\
2 \cdot 3 \\
0.9 \\
2 \cdot 0 \\
\end{array}$ & $\begin{array}{l}2.9 \\
1.8 \\
1.4 \\
1.1 \\
\end{array}$ & $\begin{array}{l}2.6 \\
2.1 \\
1.5 \\
1.9 \\
\end{array}$ & $\begin{array}{l}2.6 \\
1.6 \\
2.3 \\
2.3 \\
\end{array}$ & $\begin{array}{l}2.7 \\
1.8 \\
11.4 \\
1.8 \\
\end{array}$ & $\begin{array}{l}0.5 \\
0.9 \\
1.4 \\
1.5 \\
\end{array}$ \\
\hline & & Range .. & $\ldots$ & $1 \cdot 2$ & $1 \cdot 3$ & $1 \cdot 7$ & 1.8 & $1 \cdot 8$ & $1 \cdot 1$ & $1 \cdot 0$ & & \\
\hline \multirow[t]{2}{*}{$\begin{array}{l}540 \\
541\end{array}$} & \multirow[t]{2}{*}{$\begin{array}{l}\text { Total } \\
\text { Peptic Ulcers }\end{array}$} & $\begin{array}{l}\text { UK } . . \\
\text { BAOR.: } \\
\text { MELF }: \\
\text { FARELF }\end{array}$ & $\begin{array}{l}\because \\
\because \\
.\end{array}$ & $\begin{array}{l}4.8 \\
4.6 \\
2.2 \\
2.7\end{array}$ & $\begin{array}{l}4 \cdot 7 \\
3 \cdot 7 \\
2 \cdot 6 \\
2 \cdot 5\end{array}$ & $\begin{array}{l}5.6 \\
4 \cdot 0 \\
2.7 \\
5.0\end{array}$ & $\begin{array}{l}5 \cdot 3 \\
5 \cdot 2 \\
2 \cdot 4 \\
3 \cdot 4\end{array}$ & $\begin{array}{l}4.5 \\
4.2 \\
2.5 \\
1.9\end{array}$ & $\begin{array}{l}4 \cdot 1 \\
4 \cdot 1 \\
2 \cdot 8 \\
2 \cdot 7\end{array}$ & $\begin{array}{l}4 \cdot 2 \\
3 \cdot 0 \\
3 \cdot .8 \\
3 \cdot 3\end{array}$ & $\begin{array}{l}4 \cdot 7 \\
4.1 \\
2 \cdot 7 \\
3 \cdot 1\end{array}$ & $\begin{array}{l}1.5 \\
2.2 \\
1.6 \\
3.1\end{array}$ \\
\hline & & Range .. & .. & $2 \cdot 6$ & $2 \cdot 2$ & $2 \cdot 9$ & $2 \cdot 9$ & $2 \cdot 6$ & 1.4 & $1 \cdot 2$ & & \\
\hline
\end{tabular}




\section{APPENDIX TABLE J}

ADMISSIONS OF BRITISH ARMY MALES IN MAIN COMMANDS, 1950-1956 RATES PER 1,000 STRENGTH, VARICOSE VEINS AND HERNIA

\begin{tabular}{|c|c|c|c|c|c|c|c|c|c|c|c|c|}
\hline $\begin{array}{c}\text { Int. List } \\
\text { No. }\end{array}$ & Disease & \multicolumn{2}{|c|}{ Command } & 1950 & 1951 & 1952 & 1953 & 1954 & 1955 & 1956 & Average & Range \\
\hline \multirow[t]{2}{*}{460} & \multirow[t]{2}{*}{ Varicose Veins } & $\begin{array}{l}\text { UK } \\
\text { BAOR. } \\
\text { MELF. } \\
\text { FARELF }\end{array}$ & $\begin{array}{l}\cdots \\
\cdots \\
\cdots\end{array}$ & $\begin{array}{l}2 \cdot 7 \\
4 \cdot 2 \\
2 \cdot 7 \\
3 \cdot 6\end{array}$ & $\begin{array}{l}3 \cdot 4 \\
4 \cdot 2 \\
2 \cdot 2 \\
3 \cdot 8\end{array}$ & $\begin{array}{l}3 \cdot 2 \\
3 \cdot 2 \\
2 \cdot 4 \\
3 \cdot 5\end{array}$ & $\begin{array}{l}2 \cdot 8 \\
3 \cdot 0 \\
2 \cdot 3 \\
2 \cdot 4\end{array}$ & $\begin{array}{l}2 \cdot 6 \\
3 \cdot 3 \\
1 \cdot 6 \\
3 \cdot 2\end{array}$ & $\begin{array}{l}2 \cdot 3 \\
3 \cdot 1 \\
1 \cdot 5 \\
1 \cdot 6\end{array}$ & $\begin{array}{l}2 \cdot 2 \\
2 \cdot 5 \\
1 \cdot 7 \\
1 \cdot 7\end{array}$ & $\begin{array}{l}2 \cdot 7 \\
3 \cdot 4 \\
2 \cdot 1 \\
2 \cdot 8\end{array}$ & $\begin{array}{l}1 \cdot 2 \\
1 \cdot 7 \\
1 \cdot 2 \\
2 \cdot 2\end{array}$ \\
\hline & & Range . . & . & $1 \cdot 5$ & $2 \cdot 0$ & $1 \cdot 1$ & $0 \cdot 7$ & $1 \cdot 7$ & $1 \cdot 6$ & $0 \cdot 8$ & & \\
\hline \multirow[t]{2}{*}{$\begin{array}{l}560 \\
561\end{array}$} & \multirow[t]{2}{*}{ Hernia. . . } & $\begin{array}{l}\text { UK } \\
\text { BAOR. } \\
\text { MELF } \\
\text { FARELF }\end{array}$ & $\begin{array}{l}\cdots \\
\cdots \\
\cdots\end{array}$ & $\begin{array}{l}4 \cdot 3 \\
3 \cdot 2 \\
2 \cdot 5 \\
3 \cdot 5\end{array}$ & $\begin{array}{l}4 \cdot 2 \\
3 \cdot 5 \\
2 \cdot 4 \\
3 \cdot 1\end{array}$ & $\begin{array}{l}4 \cdot 7 \\
3 \cdot 3 \\
2 \cdot 3 \\
3 \cdot 3\end{array}$ & $\begin{array}{l}3 \cdot 6 \\
3 \cdot 3 \\
2 \cdot 4 \\
2 \cdot 6\end{array}$ & $\begin{array}{l}3 \cdot 6 \\
3 \cdot 0 \\
2 \cdot 7 \\
3 \cdot 1\end{array}$ & $\begin{array}{l}3 \cdot 4 \\
2 \cdot 7 \\
2 \cdot 2 \\
2 \cdot 7\end{array}$ & $\begin{array}{l}3 \cdot 7 \\
2 \cdot 6 \\
1 \cdot 8 \\
1 \cdot 9\end{array}$ & $\begin{array}{l}3 \cdot 9 \\
3 \cdot 1 \\
2 \cdot 3 \\
2 \cdot 9\end{array}$ & $\begin{array}{l}1 \cdot 3 \\
0 \cdot 9 \\
0 \cdot 9 \\
1 \cdot 6\end{array}$ \\
\hline & & Range . . & $\cdots$ & $1 \cdot 8$ & $1 \cdot 8$ & $2 \cdot 4$ & $1 \cdot 2$ & 0.9 & $1 \cdot 2$ & $1 \cdot 9$ & & \\
\hline
\end{tabular}

APPENDiX TABLE K

ADMISSIONS OF BRITISH ARMY MALES IN MAIN COMMANDS, 1950-1956 RATES PER 1,000 STRENGTH, PSYCHIATRIC CONDITIONS

\begin{tabular}{|c|c|c|c|c|c|c|c|c|c|c|c|c|}
\hline $\begin{array}{c}\text { Int. List } \\
\text { No. }\end{array}$ & Disease & Commar & & 1950 & 1951 & 1952 & 1953 & 1954 & 1955 & 1956 & Average & Range \\
\hline \multirow[t]{2}{*}{$300-309$} & \multirow[t]{2}{*}{ Psychoses } & $\begin{array}{l}\text { UK } . . \\
\text { BAOR.. } \\
\text { MELF... } \\
\text { FARELF }\end{array}$ & $\begin{array}{l}\cdots \\
\cdots \\
\cdots\end{array}$ & $\begin{array}{l}0.9 \\
0.9 \\
0.6 \\
0.4\end{array}$ & $\begin{array}{l}0.4 \\
0.2 \\
0.4 \\
0.6\end{array}$ & $\begin{array}{l}0.4 \\
0.4 \\
0.5 \\
1.0\end{array}$ & $\begin{array}{l}0.8 \\
1.5 \\
0.6 \\
0.8\end{array}$ & $\begin{array}{l}0.7 \\
0.8 \\
1.5 \\
0.9\end{array}$ & $\begin{array}{l}1 \cdot 0 \\
1 \cdot 0 \\
0 \cdot 7 \\
1 \cdot 1\end{array}$ & $\begin{array}{l}0 \cdot 8 \\
0 \cdot 2 \\
0 \cdot 6 \\
0.6\end{array}$ & $\begin{array}{l}0 \cdot 7 \\
0 \cdot 7 \\
0 \cdot 7 \\
0 \cdot 8\end{array}$ & $\begin{array}{l}0 \cdot 6 \\
1 \cdot 3 \\
1 \cdot 1 \\
0 \cdot 7\end{array}$ \\
\hline & & Range .. & $\cdots$ & $0 \cdot 5$ & $0 \cdot 4$ & 0.6 & 0.9 & $0 \cdot 8$ & $0 \cdot 4$ & 0.6 & & \\
\hline \multirow[t]{2}{*}{$\begin{array}{c}310-324 \\
326\end{array}$} & \multirow[t]{2}{*}{$\begin{array}{l}\text { Psychoneuroses } \\
\text { and } \\
\text { Disorders of } \\
\text { Personality .. }\end{array}$} & $\begin{array}{l}\text { UK } \\
\text { BAOR. } \\
\text { MELF } \\
\text { FARELF }\end{array}$ & $\begin{array}{l}\cdots \\
\cdots \\
\cdots\end{array}$ & $\begin{array}{l}4 \cdot 9 \\
3 \cdot 4 \\
4 \cdot 2 \\
7 \cdot 7\end{array}$ & $\begin{array}{l}5 \cdot 2 \\
2 \cdot 4 \\
3 \cdot 4 \\
5 \cdot 6\end{array}$ & $\begin{array}{l}4 \cdot 8 \\
2 \cdot 4 \\
2 \cdot 0 \\
3 \cdot 7\end{array}$ & $\begin{array}{l}3 \cdot 0 \\
2 \cdot 7 \\
3 \cdot 4 \\
4 \cdot 0\end{array}$ & $\begin{array}{l}3 \cdot 1 \\
2 \cdot 9 \\
1 \cdot 9 \\
5 \cdot 4\end{array}$ & $\begin{array}{l}3 \cdot 6 \\
3 \cdot 0 \\
3 \cdot 8 \\
2 \cdot 2\end{array}$ & $\begin{array}{l}4 \cdot 2 \\
3 \cdot 6 \\
4 \cdot 3 \\
3 \cdot 0\end{array}$ & $\begin{array}{l}4 \cdot 1 \\
2 \cdot 9 \\
3 \cdot 3 \\
4 \cdot 5\end{array}$ & $\begin{array}{l}2 \cdot 2 \\
1 \cdot 2 \\
2 \cdot 4 \\
5 \cdot 5\end{array}$ \\
\hline & & Range .. & $\cdots$ & $4 \cdot 3$ & $3 \cdot 2$ & $2 \cdot 8$ & $1 \cdot 3$ & $3 \cdot 5$ & $1 \cdot 6$ & $1 \cdot 3$ & & \\
\hline \multirow[t]{2}{*}{325} & \multirow[t]{2}{*}{$\begin{array}{l}\text { Mental } \\
\text { Deficiency .. }\end{array}$} & $\begin{array}{l}\text { UK } \\
\text { BAOR . } \\
\text { MELF. } \\
\text { FARELF }\end{array}$ & $\begin{array}{l}\cdots \\
\cdots \\
\cdots\end{array}$ & $\begin{array}{l}0 \cdot 2 \\
0 \cdot 3 \\
0 \cdot 5 \\
0 \cdot 5 \\
\end{array}$ & $\begin{array}{l}0 \cdot 2 \\
0 \cdot 1 \\
0 \cdot 2 \\
0 \cdot 5\end{array}$ & $\begin{array}{l}0 \cdot 3 \\
0 \cdot 2 \\
0 \cdot 1 \\
1 \cdot 1\end{array}$ & $\begin{array}{l}0 \cdot 8 \\
0 \cdot 3 \\
0 \cdot 4 \\
0 \cdot 3 \\
\end{array}$ & $\begin{array}{l}0 \cdot 2 \\
0 \cdot 2 \\
0 \cdot 2 \\
0 \cdot 2\end{array}$ & $\begin{array}{l}0.1 \\
0.0 \\
0.2 \\
0.0 \\
\end{array}$ & $\begin{array}{l}0 \cdot 1 \\
0 \cdot 1 \\
0 \cdot 2 \\
0 \cdot 1\end{array}$ & $\begin{array}{l}0 \cdot 3 \\
0 \cdot 2 \\
0 \cdot 3 \\
0 \cdot 4\end{array}$ & $\begin{array}{l}0 \cdot 7 \\
0 \cdot 3 \\
0 \cdot 4 \\
1 \cdot 1\end{array}$ \\
\hline & & Range .. & $\cdots$ & $0 \cdot 3$ & 0.4 & $1 \cdot 0$ & $0 \cdot 5$ & 0.0 & $0 \cdot 2$ & $0 \cdot 1$ & & \\
\hline \multirow[t]{2}{*}{-} & \multirow[t]{2}{*}{$\begin{array}{l}\text { Total } \\
\text { Psychiatric } \\
\text { Conditions .. }\end{array}$} & $\begin{array}{l}\text { UK } \\
\text { BAOR . } \\
\text { MELF. } \\
\text { FARELF }\end{array}$ & $\begin{array}{l}\cdots \\
\cdots \\
\cdots\end{array}$ & $\begin{array}{l}6 \cdot 1 \\
4 \cdot 6 \\
5 \cdot 3 \\
8 \cdot 5\end{array}$ & $\begin{array}{l}5 \cdot 8 \\
2 \cdot 7 \\
4 \cdot 0 \\
6 \cdot 7\end{array}$ & $\begin{array}{l}5 \cdot 5 \\
3 \cdot 0 \\
2 \cdot 6 \\
5 \cdot 8\end{array}$ & $\begin{array}{l}4 \cdot 6 \\
4 \cdot 5 \\
4 \cdot 3 \\
5 \cdot 1\end{array}$ & $\begin{array}{l}3 \cdot 9 \\
3 \cdot 9 \\
3 \cdot 5 \\
6 \cdot 6\end{array}$ & $\begin{array}{l}4 \cdot 6 \\
4 \cdot 0 \\
4 \cdot 7 \\
3 \cdot 3\end{array}$ & $\begin{array}{l}5 \cdot 1 \\
3 \cdot 8 \\
5 \cdot 1 \\
3 \cdot 7\end{array}$ & $\begin{array}{l}5 \cdot 1 \\
3 \cdot 8 \\
4 \cdot 2 \\
5 \cdot 7\end{array}$ & $\begin{array}{l}2 \cdot 2 \\
1 \cdot 9 \\
2 \cdot 7 \\
5 \cdot 2\end{array}$ \\
\hline & & Range . . & $\cdots$ & $3 \cdot 9$ & $4 \cdot 0$ & $3 \cdot 2$ & $0 \cdot 8$ & $3 \cdot 1$ & $1 \cdot 4$ & $1 \cdot 4$ & & \\
\hline
\end{tabular}


APPENDIX TABLE L

ADMISSIONS OF BRITISH ARMY MALES IN MAIN COMMANDS, 1950-1956

RATES PER 1,000 STRENGTH, INTERNAL DERANGEMENT OF THE KNEE AND EFFECTS OF CLIMATE

\begin{tabular}{|c|c|c|c|c|c|c|c|c|c|c|c|c|}
\hline $\begin{array}{l}\text { Int. List } \\
\text { No. }\end{array}$ & Injury & Comman & & 1950 & 1951 & 1952 & 1953 & 1954 & 1955 & 1956 & Average & Range \\
\hline \multirow[t]{2}{*}{734} & \multirow[t]{2}{*}{$\begin{array}{l}\text { Internial } \\
\text { Derangement } \\
\text { of the Knee }\end{array}$} & $\begin{array}{l}\text { UK } . . \\
\text { BAOR.. } \\
\text { MELF.: } \\
\text { FARELF }\end{array}$ & $\begin{array}{l}\cdots \\
\because \\
\cdots\end{array}$ & $\begin{array}{l}2 \cdot 5 \\
5 \cdot 5 \\
4 \cdot 6 \\
4 \cdot 7\end{array}$ & $\begin{array}{l}3 \cdot 0 \\
2 \cdot 7 \\
4 \cdot 2 \\
8 \cdot 3\end{array}$ & $\begin{array}{l}3 \cdot 1 \\
2 \cdot 3 \\
2 \cdot 4 \\
5 \cdot 4\end{array}$ & $\begin{array}{l}2 \cdot 3 \\
3 \cdot 4 \\
3 \cdot 2 \\
3 \cdot 3 \\
\end{array}$ & $\begin{array}{l}3 \cdot 2 \\
5 \cdot 4 \\
2 \cdot 2 \\
2 \cdot 6\end{array}$ & $\begin{array}{l}3 \cdot 8 \\
4 \cdot 2 \\
2 \cdot 6 \\
2 \cdot 8\end{array}$ & $\begin{array}{l}4 \cdot 3 \\
3 \cdot 1 \\
1.9 \\
3 \cdot 8\end{array}$ & $\begin{array}{l}3 \cdot 2 \\
3.8 \\
3.0 \\
4 \cdot 4\end{array}$ & $\begin{array}{l}2 \cdot 0 \\
3 \cdot 2 \\
2 \cdot 7 \\
5 \cdot 7\end{array}$ \\
\hline & & Range ... & . & $3 \cdot 0$ & $5 \cdot 6$ & $3 \cdot 1$ & $1 \cdot 1$ & $3 \cdot 2$ & $1 \cdot 6$ & $2 \cdot 4$ & & \\
\hline \multirow[t]{2}{*}{$\begin{array}{r}\text { N } 981 \cdot 0 \\
981 \cdot 1 \\
981 \cdot 2 \\
981 \cdot 3\end{array}$} & \multirow[t]{2}{*}{ Effects of Heat } & $\begin{array}{l}\text { UK } \\
\text { BAOR.: } \\
\text { MELF. } \\
\text { FARELF }\end{array}$ & $\begin{array}{l}\cdots \\
\cdots \\
\cdots\end{array}$ & $\begin{array}{l}0.1 \\
0.6 \\
1.5\end{array}$ & $\begin{array}{l}0.0 \\
0.0 \\
1.9 \\
1.1 \\
\end{array}$ & $\begin{array}{l}0.1 \\
0.0 \\
1.7 \\
1.1 \\
\end{array}$ & $\begin{array}{l}0.0 \\
0 \cdot 1 \\
1.7 \\
2.2 \\
\end{array}$ & $\begin{array}{l}0.0 \\
0.1 \\
0.6 \\
1.4 \\
\end{array}$ & $\begin{array}{l}0.1 \\
0.1 \\
1.7 \\
1.1 \\
\end{array}$ & $\begin{array}{l}0.0 \\
0.0 \\
1.8 \\
1.7 \\
\end{array}$ & $\begin{array}{l}0.0 \\
0.0 \\
1.4 \\
1.4 \\
\end{array}$ & $\begin{array}{l}0 \cdot 1 \\
0 \cdot 1 \\
1 \cdot 3 \\
1 \cdot 1 \\
\end{array}$ \\
\hline & & Range ... & $\cdots$ & $1 \cdot 5$ & 1.9 & $1 \cdot 7$ & $2 \cdot 2$ & $1 \cdot 4$ & 1.6 & $1 \cdot 8$ & & \\
\hline \multirow[t]{2}{*}{$\begin{array}{r}\text { N } 980 \cdot 0 \\
980 \cdot 1\end{array}$} & \multirow[t]{2}{*}{ Effects of Cold } & $\begin{array}{l}\text { UK } \\
\text { BAOR... } \\
\text { MELF.: } \\
\text { FARELF }\end{array}$ & $\begin{array}{l}\cdots \\
\cdots \\
\cdots \\
\end{array}$ & $\begin{array}{l}\bar{Z} \\
\overline{0.0} \\
0 \cdot 0\end{array}$ & $\begin{array}{l}\overline{0.0} \\
-\end{array}$ & $\begin{array}{l}0.0 \\
0.0 \\
0.0 \\
\end{array}$ & $\begin{array}{l}0.0 \\
0.0 \\
- \\
\end{array}$ & $\begin{array}{l}0.0 \\
0.1 \\
0.0\end{array}$ & $\begin{array}{l}0.0 \\
0.4 \\
0.0 \\
\end{array}$ & $\begin{array}{l}0 \cdot 0 \\
2 \cdot 1 \\
= \\
-\end{array}$ & $\begin{array}{l}0.0 \\
0.4 \\
0.0 \\
0.0\end{array}$ & $\begin{array}{l}0.0 \\
2.1 \\
0.0 \\
0.0\end{array}$ \\
\hline & & Range ... & . & $0 \cdot 0$ & 0.0 & 0.0 & 0.0 & $0 \cdot 1$ & 0.4 & $2 \cdot 1$ & & \\
\hline
\end{tabular}

APPENDIX TABLE M

DEATHS-BRITISH ARMY MALES

Actual Numbers of Cases

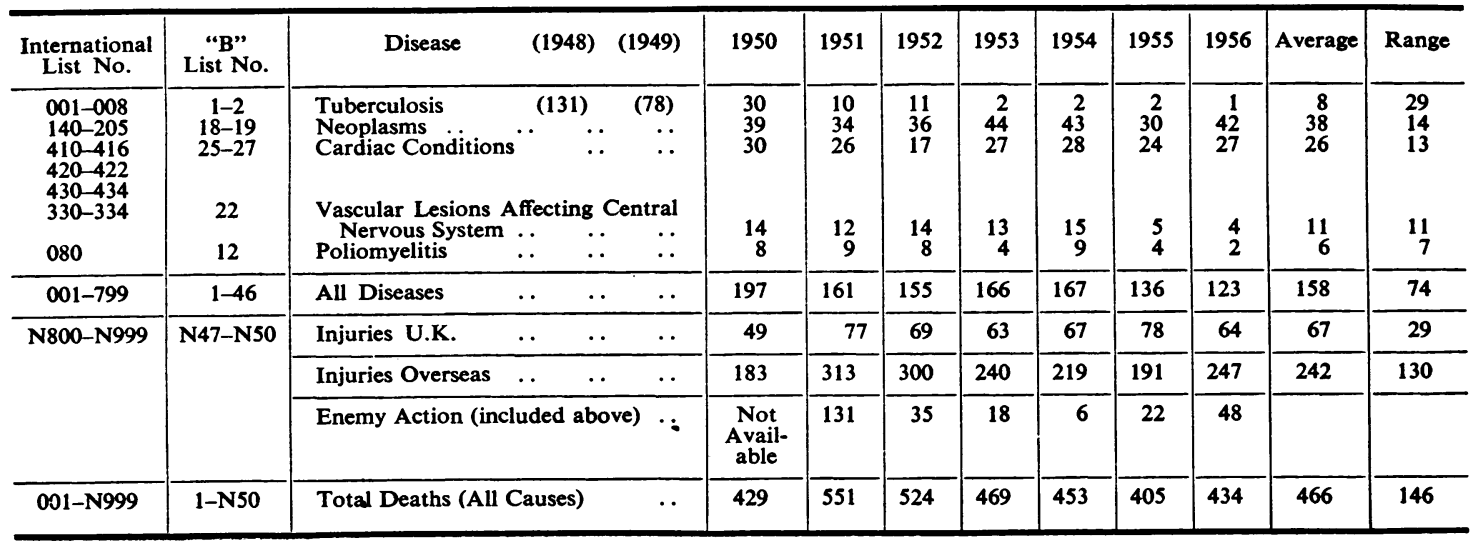

\section{APPENDIX TABLE N}

SEASONAL FLUCTUATIONS IN ADMISSION RATES FOR CERTAIN DISEASES Percentage each month of admission rates for the year, percentages averaged over 1950-1956, United Kingdom

\begin{tabular}{|c|c|c|c|c|c|c|c|c|c|c|c|c|c|c|c|}
\hline Disease & & Jan. & Feb. & Mar. & Apr. & May & June & July & Aug. & Sept. & Oct. & Nov. & Dec. & Total & $\begin{array}{c}\text { Annual Rate } \\
\text { per } \\
1,000 \text { Strength }\end{array}$ \\
\hline 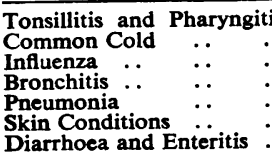 & $\begin{array}{l}\text { tis } \\
\cdots \\
\cdots \\
\cdots \\
\cdots\end{array}$ & $\begin{array}{r}9 \cdot 5 \\
17 \cdot 7 \\
26 \cdot 4 \\
13 \cdot 3 \\
14 \cdot 1 \\
8 \cdot 1 \\
8 \cdot 5\end{array}$ & $\begin{array}{r}12 \cdot 2 \\
16 \cdot 6 \\
19 \cdot 2 \\
12 \cdot 9 \\
13 \cdot 5 \\
9 \cdot 0 \\
8 \cdot 8\end{array}$ & $\begin{array}{r}13 \cdot 6 \\
14 \cdot 8 \\
16 \cdot 2 \\
12 \cdot 1 \\
12 \cdot 9 \\
8 \cdot 5 \\
7 \cdot 1\end{array}$ & $\begin{array}{r}10 \cdot 2 \\
6 \cdot 9 \\
6 \cdot 8 \\
7 \cdot 0 \\
9 \cdot 8 \\
7 \cdot 4 \\
6 \cdot 4\end{array}$ & $\begin{array}{l}9 \cdot 9 \\
5 \cdot 8 \\
4 \cdot 2 \\
6 \cdot 6 \\
8 \cdot 4 \\
8 \cdot 4 \\
7 \cdot 6\end{array}$ & $\begin{array}{l}7 \cdot 9 \\
4 \cdot 3 \\
2 \cdot 3 \\
5 \cdot 0 \\
6 \cdot 8 \\
8 \cdot 7 \\
8 \cdot 8\end{array}$ & $\begin{array}{l}6 \cdot 3 \\
3 \cdot 3 \\
2 \cdot 0 \\
4 \cdot 7 \\
5 \cdot 4 \\
8 \cdot 5 \\
9 \cdot 6\end{array}$ & $\begin{array}{l}5 \cdot 8 \\
2 \cdot 8 \\
1 \cdot 9 \\
4 \cdot 9 \\
4 \cdot 0 \\
7 \cdot 5 \\
8 \cdot 2\end{array}$ & $\begin{array}{l}6 \cdot 0 \\
5 \cdot 3 \\
2 \cdot 6 \\
6 \cdot 6 \\
4 \cdot 7 \\
9 \cdot 0 \\
9 \cdot 1\end{array}$ & $\begin{array}{l}5 \cdot 8 \\
5 \cdot 9 \\
4 \cdot 1 \\
8 \cdot 2 \\
5 \cdot 3 \\
9 \cdot 3 \\
9 \cdot 4\end{array}$ & $\begin{array}{r}6 \cdot 8 \\
7.6 \\
6 \cdot 6 \\
9 \cdot 5 \\
7 \cdot 2 \\
9 \cdot 2 \\
10 \cdot 5\end{array}$ & $\begin{array}{l}6 \cdot 2 \\
9 \cdot 1 \\
7 \cdot 6 \\
9 \cdot 1 \\
7 \cdot 6 \\
6 \cdot 2 \\
6 \cdot 2\end{array}$ & $\begin{array}{l}100 \\
100 \\
100 \\
100 \\
100 \\
100 \\
100\end{array}$ & $\begin{array}{r}37 \cdot 5 \\
23 \cdot 8 \\
14 \cdot 1 \\
8 \cdot 2 \\
3 \cdot 8 \\
33 \cdot 0 \\
5 \cdot 7\end{array}$ \\
\hline All Diseases & $\cdots$ & $11 \cdot 1$ & $11 \cdot 1$ & $10 \cdot 4$ & $8 \cdot 1$ & $8 \cdot 4$ & $8 \cdot 0$ & $7 \cdot 2$ & $6 \cdot 5$ & $7 \cdot 3$ & $7 \cdot 5$ & $8 \cdot 2$ & $6 \cdot 4$ & 100 & $260 \cdot 9$ \\
\hline
\end{tabular}


APPENDix TABLE $O$

SEASONAL FLUCTUATIONS IN ADMISSION RATES FOR CERTAIN DISEASES

Percentage each month of admission rates for the year, percentages averaged over 1950-1956, British Army of the Rhine

\begin{tabular}{|c|c|c|c|c|c|c|c|c|c|c|c|c|c|c|c|}
\hline Disease & & Jan. & Feb. & Mar. & Apr. & May & June & July & Aug. & Sept. & Oct. & Nov. & Dec. & Total & $\begin{array}{c}\text { Annual Rate } \\
\text { per } \\
1,000 \text { Strength }\end{array}$ \\
\hline 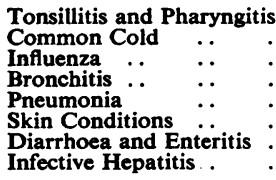 & $\begin{array}{l}\text { is } \\
\cdots \\
\cdots \\
\cdots \\
\cdots \\
\cdots\end{array}$ & $\begin{array}{r}10 \cdot 9 \\
18 \cdot 7 \\
17 \cdot 4 \\
12 \cdot 1 \\
11 \cdot 7 \\
8 \cdot 4 \\
5 \cdot 9 \\
11 \cdot 5\end{array}$ & $\begin{array}{r}10 \cdot 8 \\
15 \cdot 6 \\
25 \cdot 5 \\
11 \cdot 2 \\
13 \cdot 1 \\
8 \cdot 4 \\
8 \cdot 0 \\
11 \cdot 5\end{array}$ & $\begin{array}{l}11 \cdot 1 \\
11 \cdot 9 \\
16 \cdot 6 \\
10 \cdot 8 \\
9 \cdot 9 \\
8 \cdot 4 \\
5 \cdot 7 \\
7 \cdot 1\end{array}$ & $\begin{array}{l}8 \cdot 5 \\
6 \cdot 3 \\
9 \cdot 2 \\
7 \cdot 2 \\
7 \cdot 2 \\
8 \cdot 0 \\
5 \cdot 5 \\
6 \cdot 4\end{array}$ & $\begin{array}{l}7 \cdot 6 \\
5 \cdot 2 \\
3 \cdot 6 \\
5 \cdot 7 \\
7 \cdot 0 \\
8 \cdot 5 \\
7 \cdot 5 \\
8 \cdot 6\end{array}$ & $\begin{array}{l}6 \cdot 5 \\
3 \cdot 9 \\
2 \cdot 6 \\
6 \cdot 3 \\
7 \cdot 7 \\
7 \cdot 8 \\
8 \cdot 2 \\
7 \cdot 0\end{array}$ & $\begin{array}{l}6 \cdot 6 \\
3 \cdot 8 \\
3 \cdot 3 \\
6 \cdot 6 \\
6 \cdot 9 \\
8 \cdot 1 \\
8 \cdot 0 \\
6 \cdot 8\end{array}$ & $\begin{array}{r}6 \cdot 9 \\
3 \cdot 5 \\
3 \cdot 0 \\
4 \cdot 7 \\
5 \cdot 0 \\
8 \cdot 2 \\
12 \cdot 5 \\
8 \cdot 7\end{array}$ & $\begin{array}{r}9 \cdot 2 \\
8 \cdot 5 \\
4 \cdot 6 \\
8 \cdot 0 \\
6 \cdot 2 \\
9 \cdot 8 \\
15 \cdot 4 \\
7 \cdot 5\end{array}$ & $\begin{array}{r}7 \cdot 2 \\
8 \cdot 8 \\
4 \cdot 1 \\
10 \cdot 4 \\
7 \cdot 2 \\
9 \cdot 0 \\
9 \cdot 2 \\
8 \cdot 4\end{array}$ & $\begin{array}{l}7 \cdot 6 \\
6 \cdot 3 \\
4 \cdot 6 \\
8 \cdot 5 \\
7 \cdot 3 \\
8 \cdot 5 \\
7 \cdot 5 \\
9 \cdot 3\end{array}$ & $\begin{array}{r}7 \cdot 2 \\
7.7 \\
5 \cdot 6 \\
8 \cdot 4 \\
10 \cdot 0 \\
6 \cdot 9 \\
6 \cdot 5 \\
7 \cdot 5\end{array}$ & $\begin{array}{l}100 \\
100 \\
100 \\
100 \\
100 \\
100 \\
100 \\
100\end{array}$ & $\begin{array}{r}25 \cdot 0 \\
6 \cdot 9 \\
7 \cdot 7 \\
4 \cdot 3 \\
2 \cdot 4 \\
41 \cdot 5 \\
4 \cdot 1 \\
1 \cdot 4\end{array}$ \\
\hline All Diseases & . & $9 \cdot 8$ & $10 \cdot 0$ & $9 \cdot 0$ & $8 \cdot 0$ & $7 \cdot 9$ & $7 \cdot 7$ & $7 \cdot 9$ & $7 \cdot 8$ & $8 \cdot 7$ & $8 \cdot 4$ & $8 \cdot 2$ & $6 \cdot 5$ & 100 & $240 \cdot 9$ \\
\hline
\end{tabular}

APPENDIX TABLE $P$

SEASONAL FLUCTUATIONS IN ADMISSION RATES FOR CERTAIN DISEASES

Percentage each month of admission rates for the year, percentages averaged over 1950-1956, Middle East Land Forces

\begin{tabular}{|c|c|c|c|c|c|c|c|c|c|c|c|c|c|c|}
\hline Diseases & Jan. & Feb. & Mar. & Apr. & May & June & July & Aug. & Sept. & Oct. & Nov. & Dec. & Total & $\begin{array}{c}\text { Annual Rate } \\
\text { per } \\
1,000 \text { Strength }\end{array}$ \\
\hline $\begin{array}{l}\text { Tonsillitis and Pharyngitis } \\
\text { Otitis Externa and Media .. } \\
\text { Skin Conditions . . } \\
\text { Dysentery (other than }\end{array}$ & $\begin{array}{r}10 \cdot 2 \\
5 \cdot 5 \\
7 \cdot 7\end{array}$ & $\begin{array}{l}9 \cdot 4 \\
4 \cdot 7 \\
8 \cdot 1\end{array}$ & $\begin{array}{l}9 \cdot 1 \\
4 \cdot 2 \\
7 \cdot 6\end{array}$ & $\begin{array}{l}7 \cdot 8 \\
5 \cdot 5 \\
7 \cdot 7\end{array}$ & $\begin{array}{l}7 \cdot 7 \\
7 \cdot 8 \\
8 \cdot 0\end{array}$ & $\begin{array}{r}8 \cdot 0 \\
10 \cdot 0 \\
8 \cdot 0\end{array}$ & $\begin{array}{r}7 \cdot 6 \\
14 \cdot 1 \\
8 \cdot 5\end{array}$ & $\begin{array}{r}7 \cdot 6 \\
12 \cdot 7 \\
9 \cdot 1\end{array}$ & $\begin{array}{r}7 \cdot 1 \\
11 \cdot 9 \\
9 \cdot 0\end{array}$ & $\begin{array}{r}8 \cdot 4 \\
10 \cdot 3 \\
9 \cdot 5\end{array}$ & $\begin{array}{l}8 \cdot 8 \\
7 \cdot 7 \\
9 \cdot 2\end{array}$ & $\begin{array}{l}8 \cdot 2 \\
5 \cdot 9 \\
7 \cdot 6\end{array}$ & $\begin{array}{l}100 \\
100 \\
100\end{array}$ & $\begin{array}{r}34 \cdot 8 \\
9 \cdot 9 \\
51 \cdot 5\end{array}$ \\
\hline 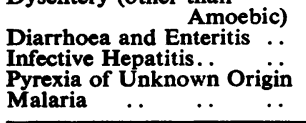 & $\begin{array}{r}1 \cdot 5 \\
2 \cdot 6 \\
11 \cdot 9 \\
4 \cdot 4 \\
3 \cdot 6\end{array}$ & $\begin{array}{l}0 \cdot 9 \\
2 \cdot 2 \\
7 \cdot 4 \\
4 \cdot 1 \\
5 \cdot 2\end{array}$ & $\begin{array}{l}2 \cdot 0 \\
3 \cdot 1 \\
4 \cdot 1 \\
5 \cdot 3 \\
3 \cdot 2\end{array}$ & $\begin{array}{l}8 \cdot 2 \\
8 \cdot 0 \\
2 \cdot 7 \\
7 \cdot 5 \\
5 \cdot 0\end{array}$ & $\begin{array}{r}11 \cdot 7 \\
11 \cdot 2 \\
3 \cdot 5 \\
9 \cdot 9 \\
7 \cdot 3\end{array}$ & $\begin{array}{r}15 \cdot 5 \\
12 \cdot 9 \\
5 \cdot 8 \\
10 \cdot 5 \\
10 \cdot 4\end{array}$ & $\begin{array}{r}14 \cdot 5 \\
12 \cdot 8 \\
6 \cdot 7 \\
12 \cdot 3 \\
9 \cdot 9\end{array}$ & $\begin{array}{r}11 \cdot 9 \\
12 \cdot 5 \\
8 \cdot 2 \\
12 \cdot 5 \\
14 \cdot 0\end{array}$ & $\begin{array}{l}12 \cdot 7 \\
13 \cdot 3 \\
10 \cdot 6 \\
12 \cdot 2 \\
16 \cdot 0\end{array}$ & $\begin{array}{r}9 \cdot 3 \\
10 \cdot 2 \\
13 \cdot 6 \\
9 \cdot 1 \\
15 \cdot 0\end{array}$ & $\begin{array}{r}7 \cdot 7 \\
7 \cdot 0 \\
14 \cdot 8 \\
7 \cdot 4 \\
5 \cdot 1\end{array}$ & $\begin{array}{r}4 \cdot 0 \\
4 \cdot 4 \\
10 \cdot 9 \\
4 \cdot 8 \\
5 \cdot 2\end{array}$ & $\begin{array}{l}100 . \\
100 \\
100 \\
100 \\
100\end{array}$ & $\begin{array}{r}20 \cdot 3 \\
37 \cdot 4 \\
5 \cdot 1 \\
21 \cdot 2 \\
4 \cdot 9\end{array}$ \\
\hline All Diseases & $6 \cdot 8$ & $6 \cdot 4$ & $6 \cdot 3$ & $7 \cdot 3$ & $8 \cdot 6$ & $9 \cdot 7$ & $10 \cdot 0$ & $10 \cdot 0$ & $10 \cdot 5$ & $9 \cdot 6$ & $8 \cdot 4$ & $6 \cdot 3$ & 100 & $328 \cdot 9$ \\
\hline
\end{tabular}

APPENDIX TABLE $Q$

SEASONAL FLUCTUATIONS IN ADMISSION RATES FOR CERTAIN DISEASES

Percentage each month of admission rates for the year, percentages averaged over 1950-1956, Far East Land Forces

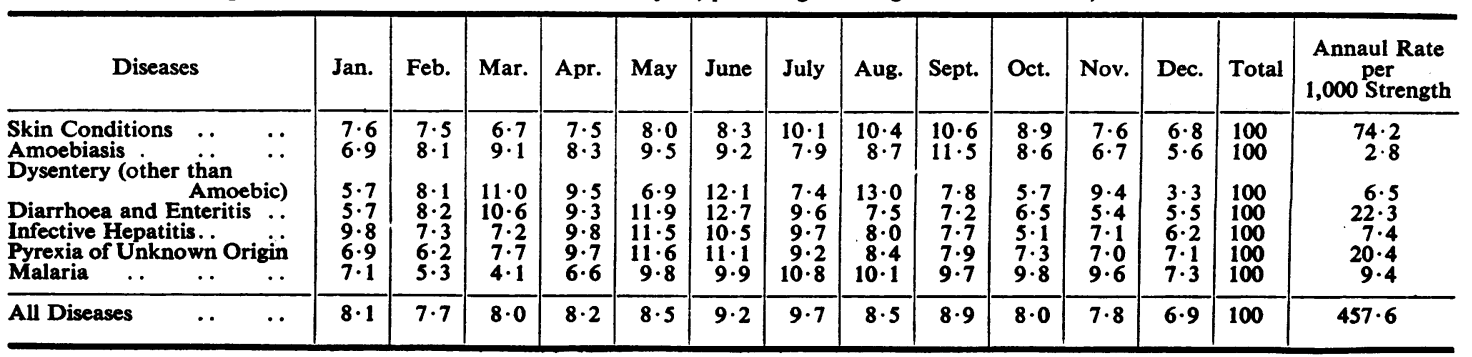


APPENDIX TABLE R

AVERAGE ADMISSION RATES PER 1,000 STRENGTH BY AGE GROUPS, 1951-1952 British Army Males

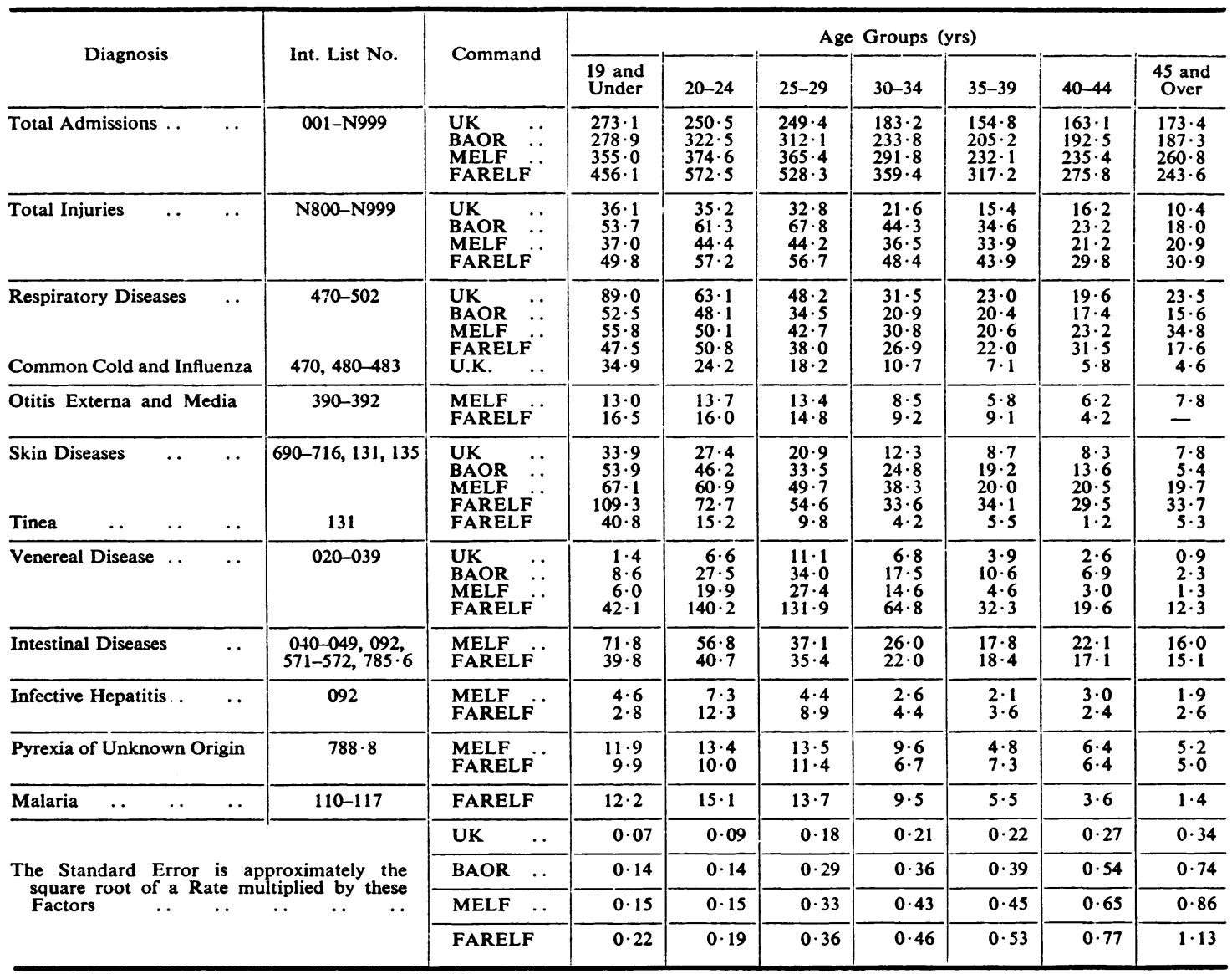

